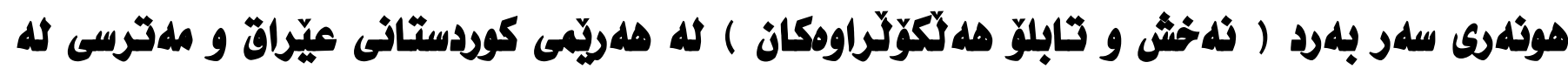 ناوجووذيان
}

\section{روخسار رمضان احمد}

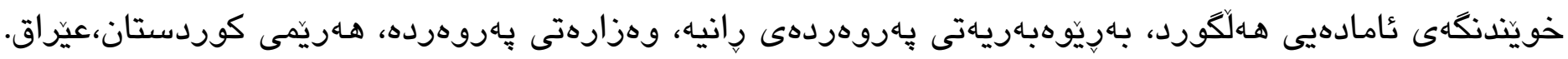
rukhsar.ramazan@gmail.com : ئيمايلّ

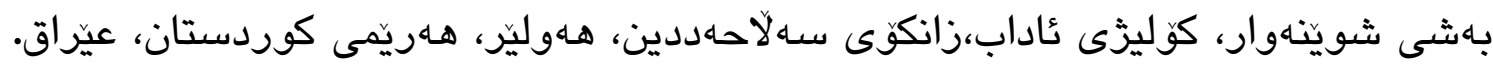
كُاراس اسماعيل خظر Aras.khider@su.edu.krd :يمـايلّ

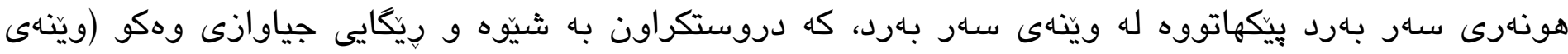

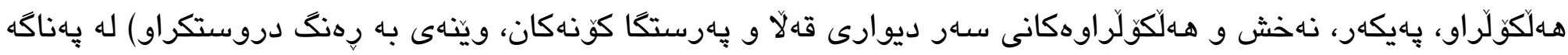

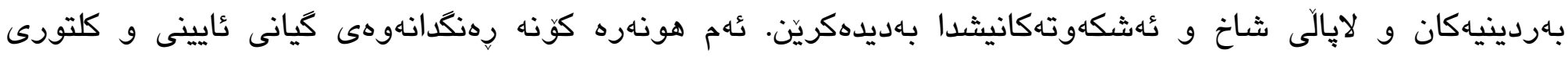

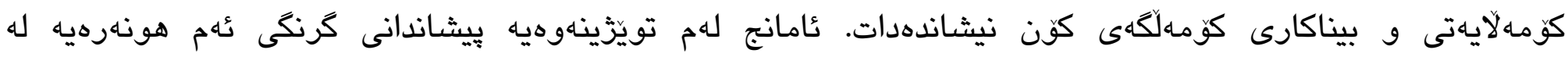

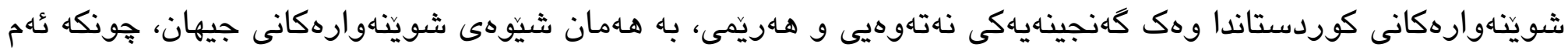

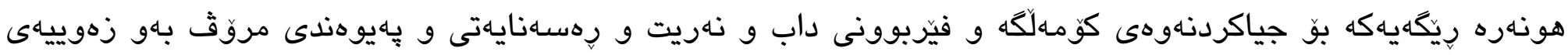
لهسارى نيشتهجي بووه. 


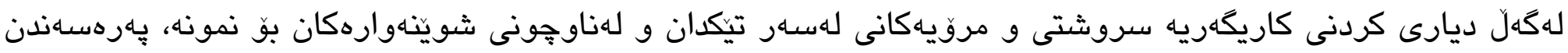

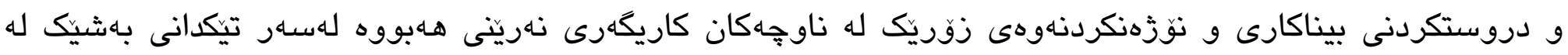

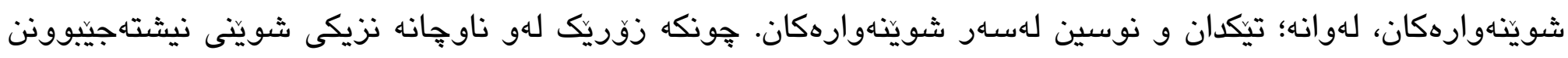

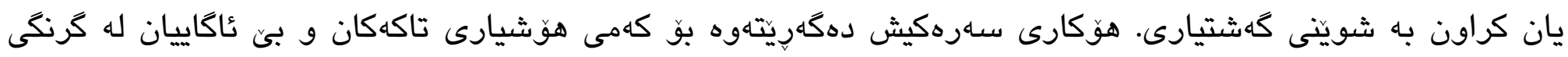

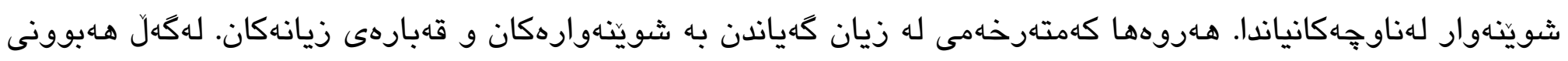

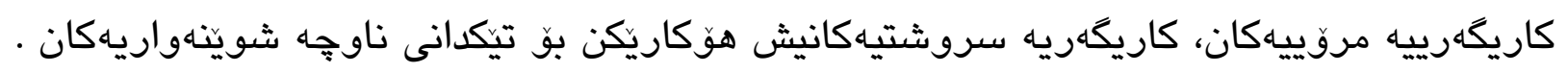

تويّزّينهوهك له جهند تهوهرهيه بيكهاتووه:

تلهوهرهى يلهكهم: ناساندنى هونهرى سهاربارد و كورتهيهكى ميزّوويى و جوّرهكانى ئهم هونهره و ئامانج و مهبهاستى مروّث

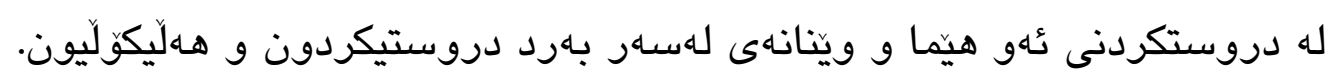

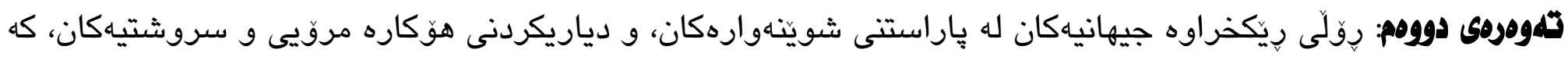

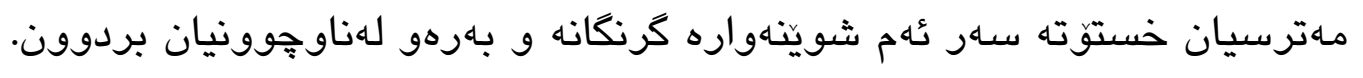

تلهوهرى سيّيلهم: دهرهنجام و رِاسيّاردهان، دياريكردنى جهند بنهمايهكى ياسايى بو كهمكردنهوهى مهترسيهكان لهسهار ئهم

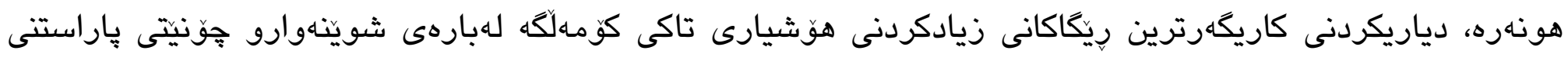
شوينتهوارهكان.

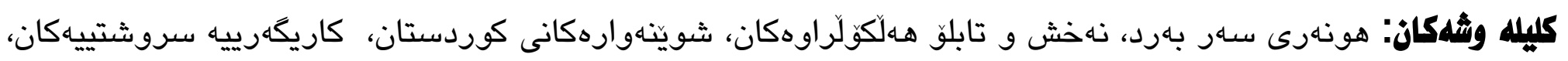
كاريكهرييه مروّيهكان. 


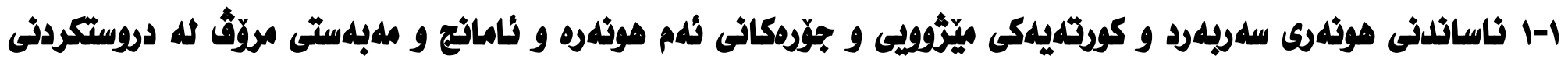

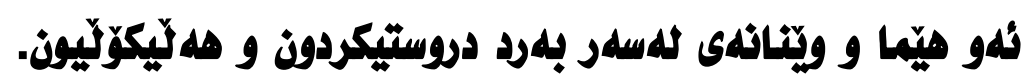

شوينهاوارهانى هونهرى سهر بهرد به بهشيك له مهزنترين كاره هونهرييهكانى جيهان دادهنرين له روانكاهى

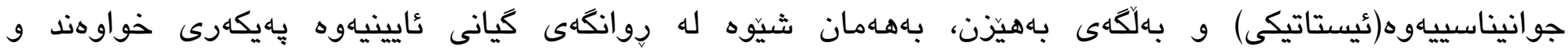

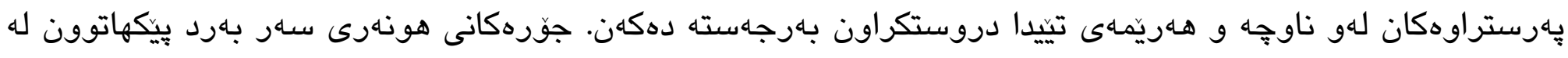

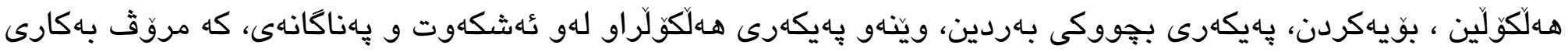

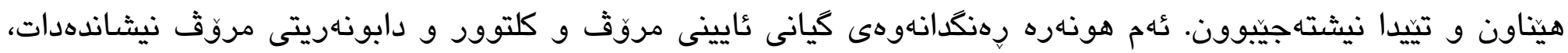

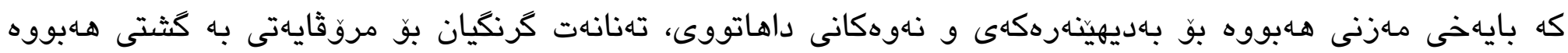

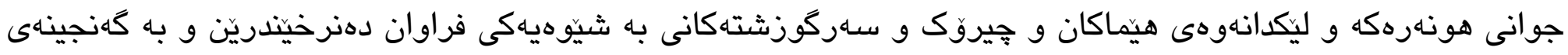

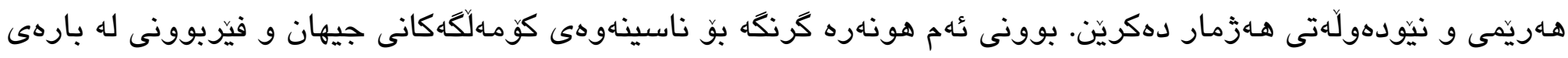

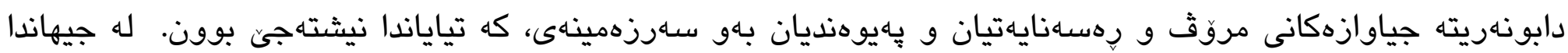

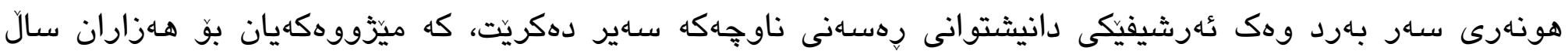

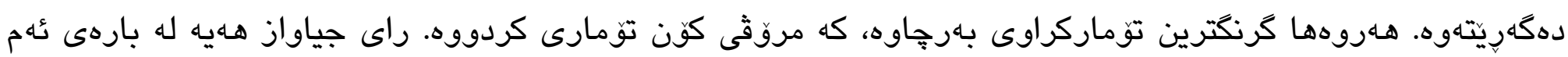

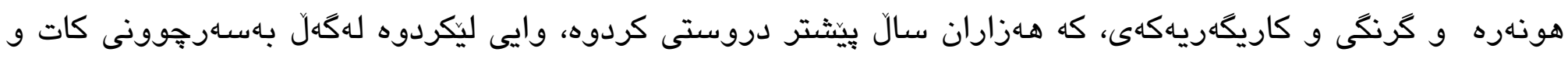

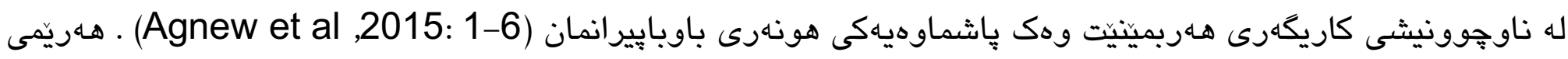

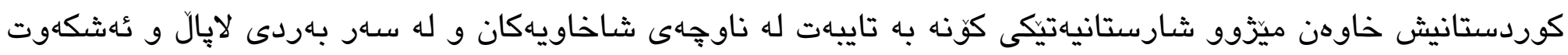

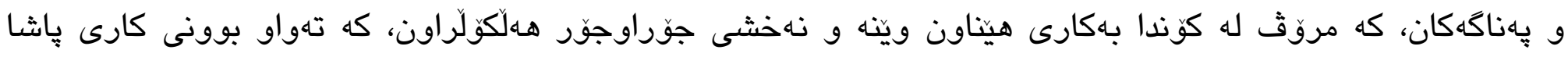

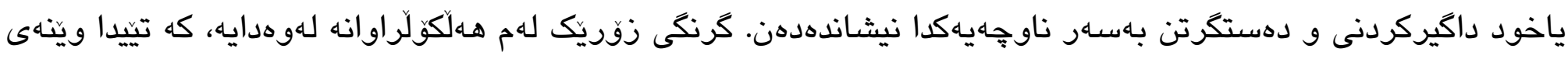

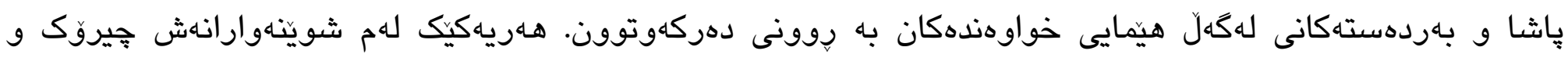

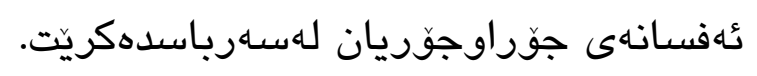

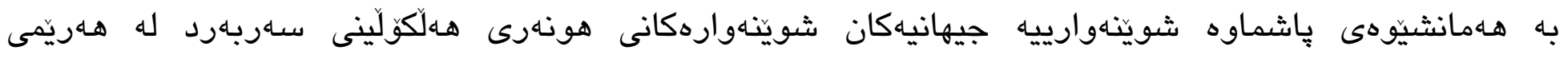

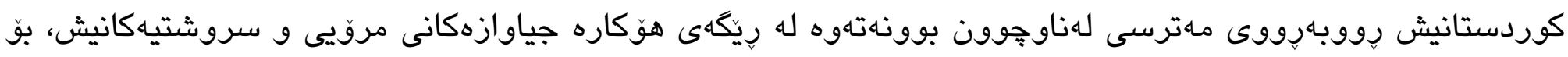
نموونه : 1- 1- (1) هوَكاره مروّيهكان.

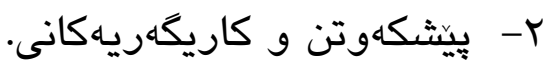




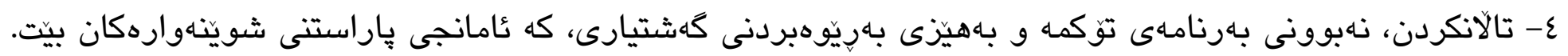
ه- هـروهها كاريكهرييه سروشتييهكان. له سهرتاسهرى جيهاندا له جهاندين سالى رابردوودا زمارهيهكى زور له

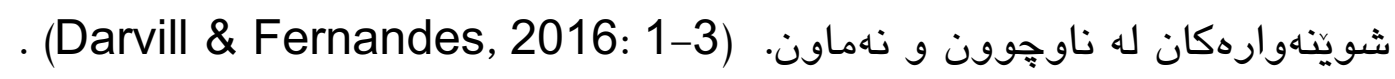

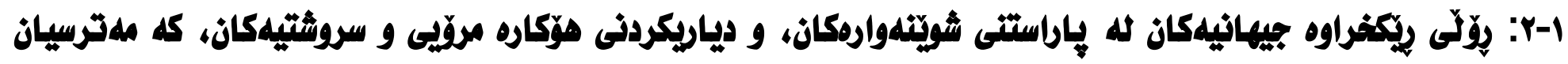

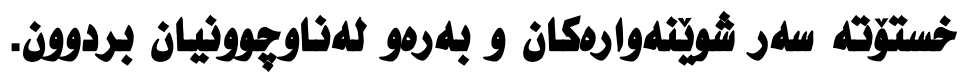

ساهبارهت به بهيانتامه نيودهولهتيهكان پِاريّزكارى كردنى شوينّهوار و شارستانيهت و كهلهيوور له لايهن رِيكخراوه

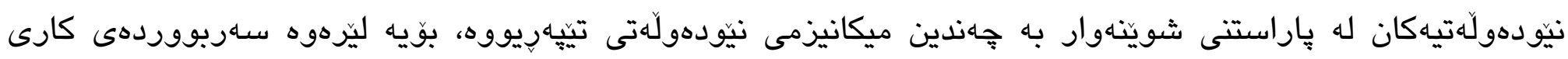
ريكخراودكان دهخهينه رِوو.

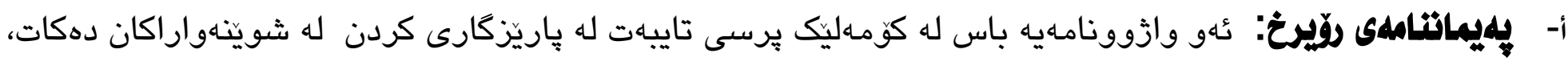

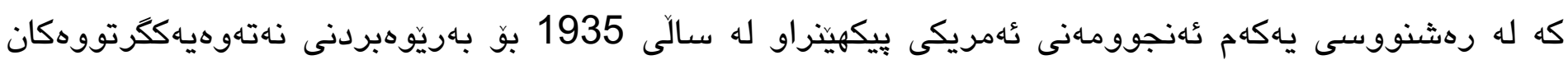

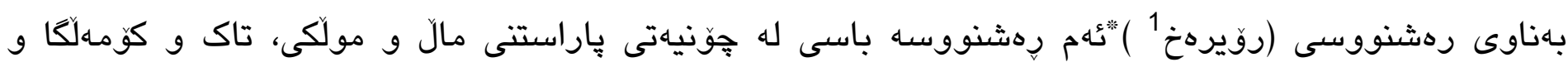

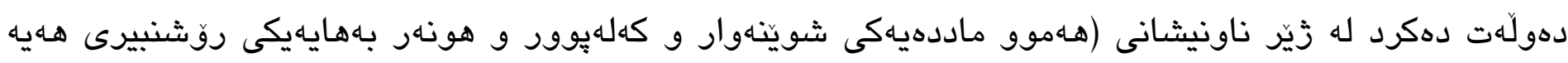

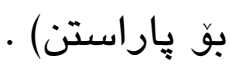

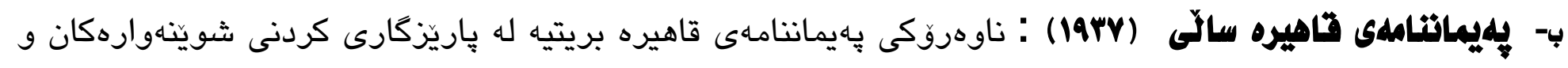

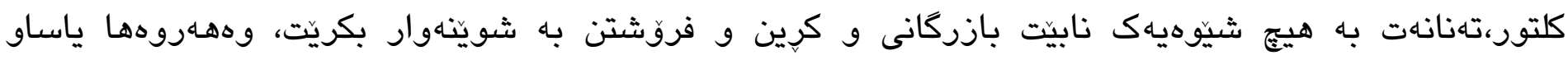

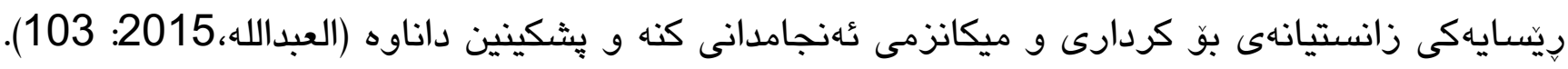

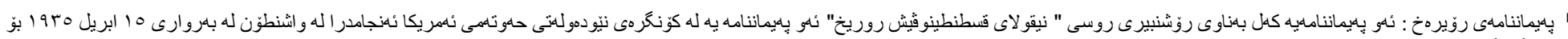

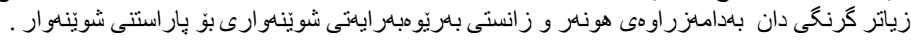




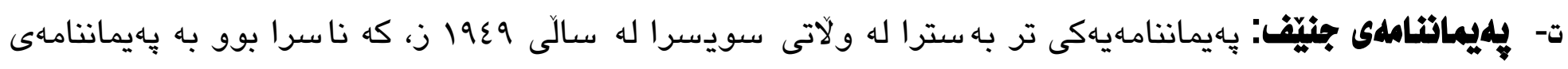

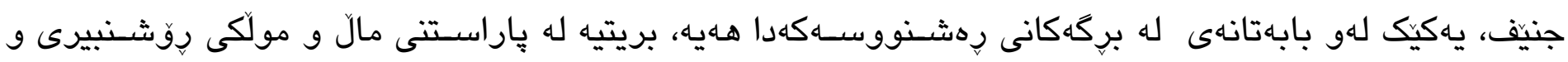

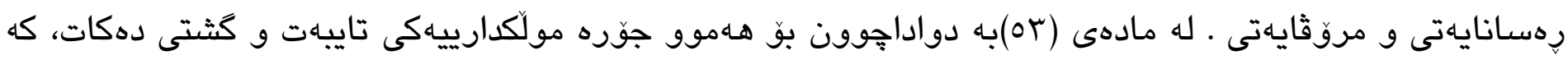

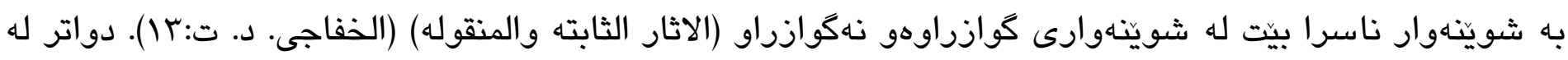

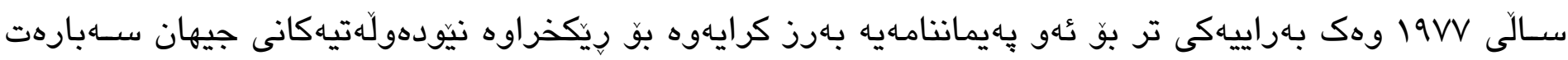

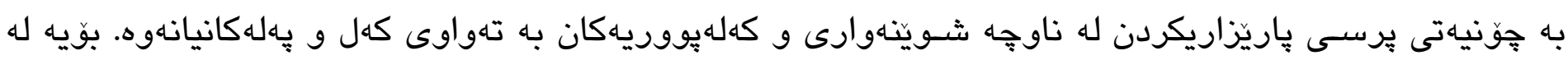

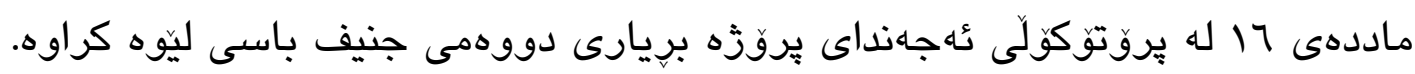

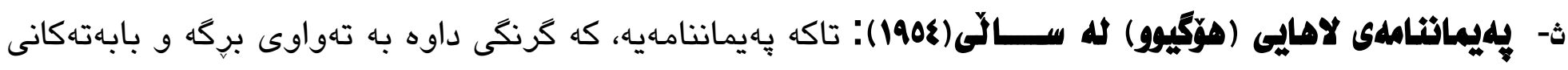

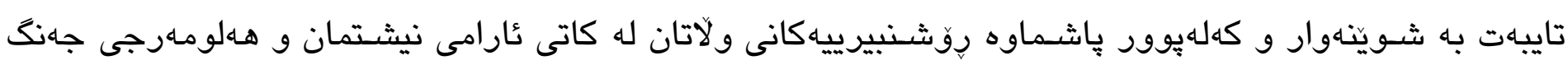

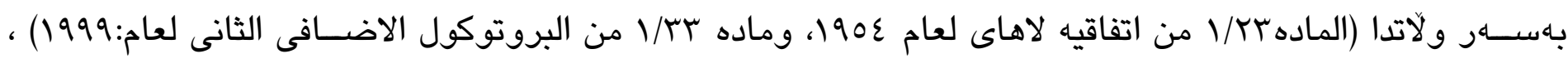

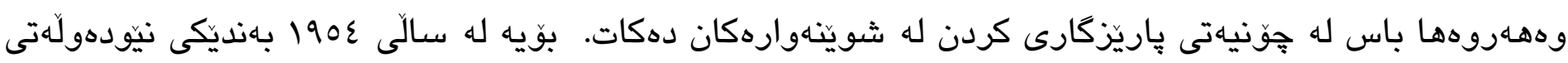

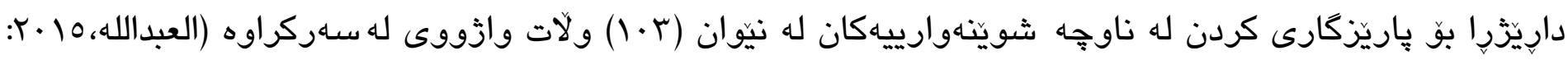

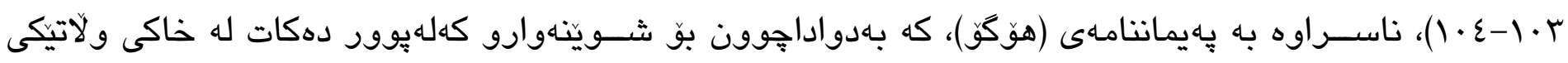

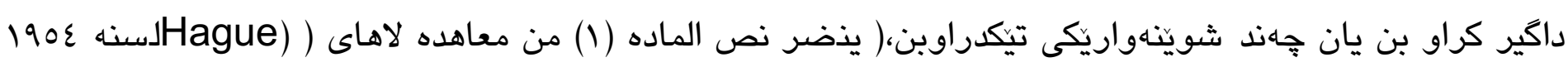
والخاصه بحمايه الممتلكات الثقافيه فى حاله النزاع المسلح).

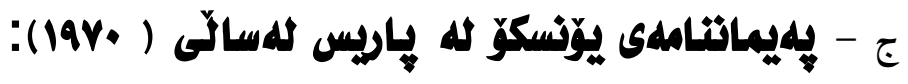

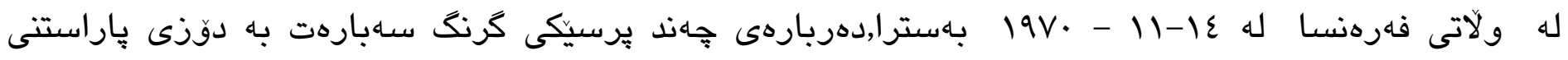

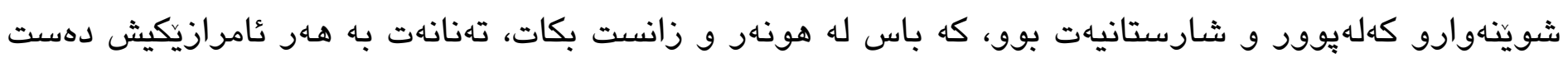

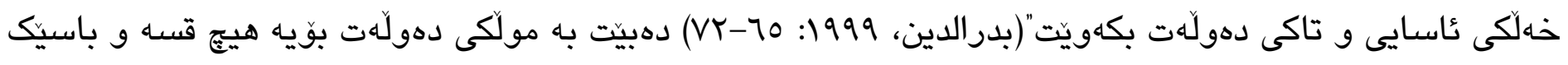

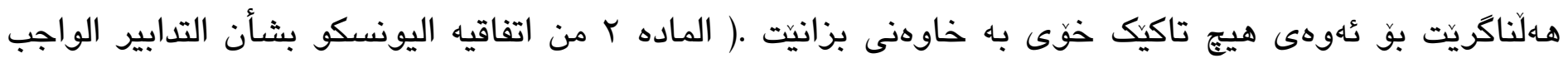

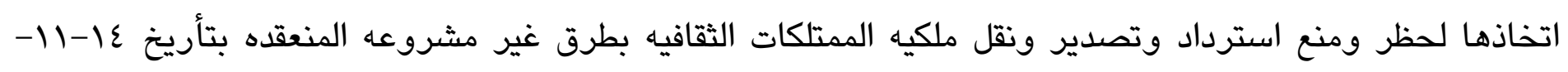

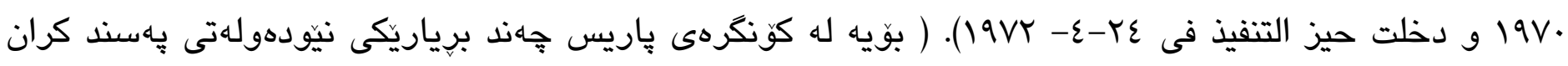

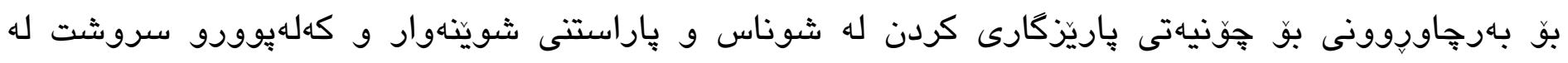

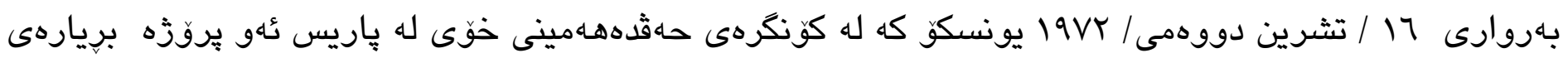

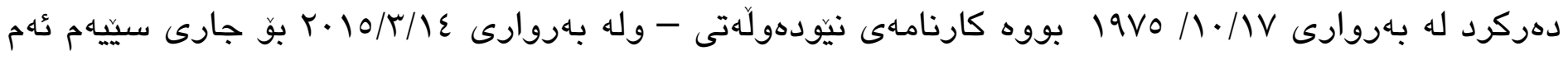

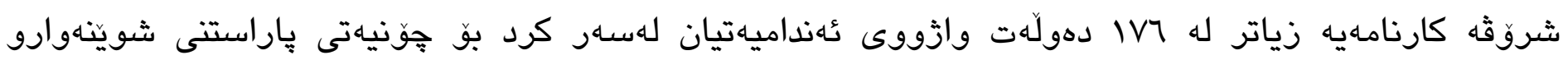


كهلهيوور وسروشت كه له بم ماده يِيكهاتبوو) (اتفاقيه لحمايه التراث العالمى الثقافى والطبيعى: 17 تشرينى الثانى /

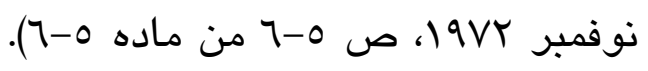

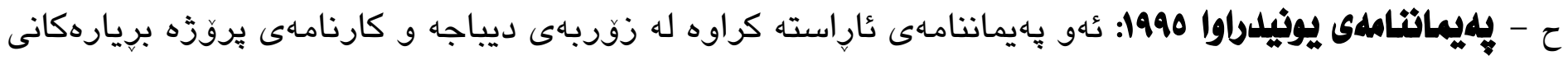

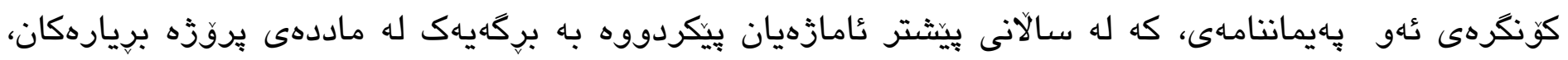

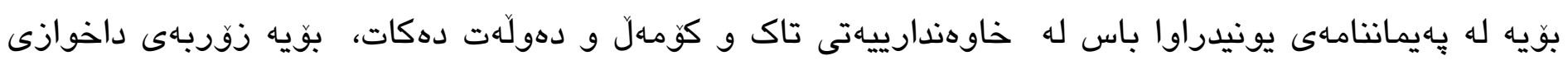

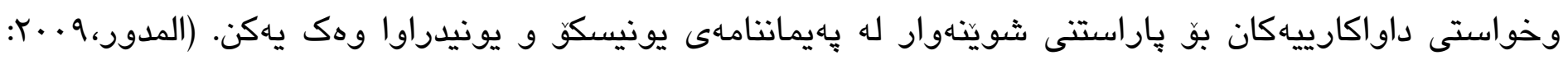

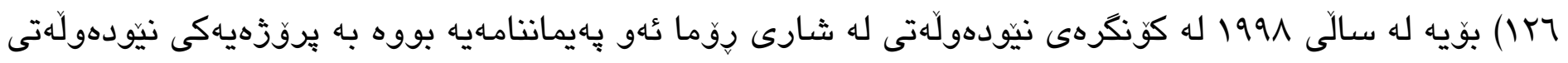

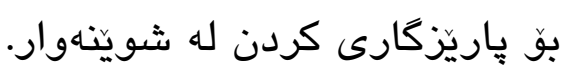

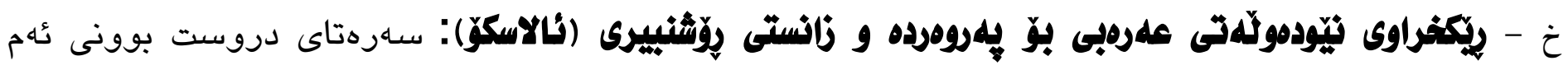

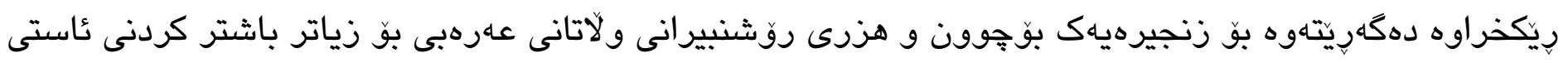

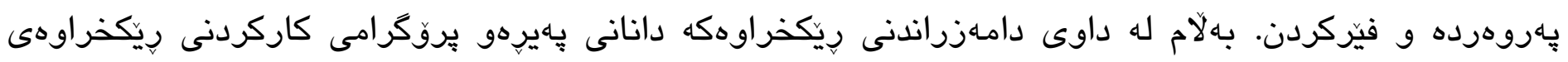

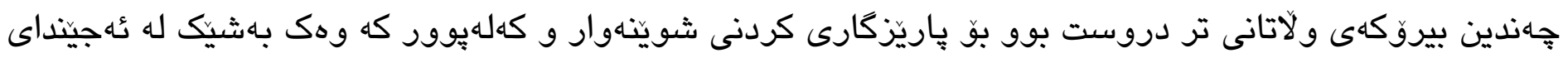

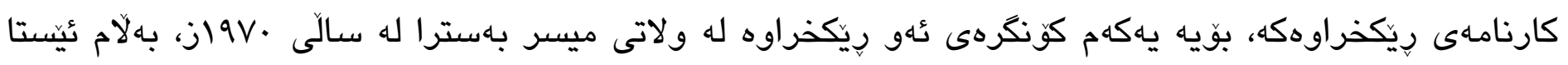

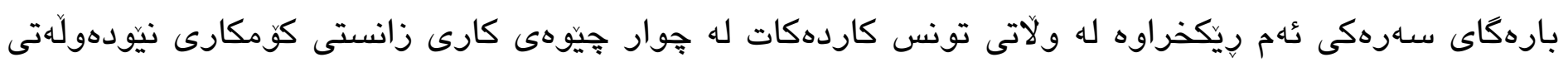

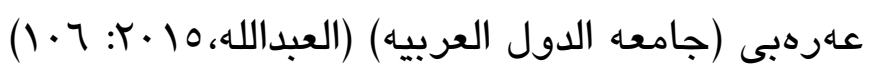

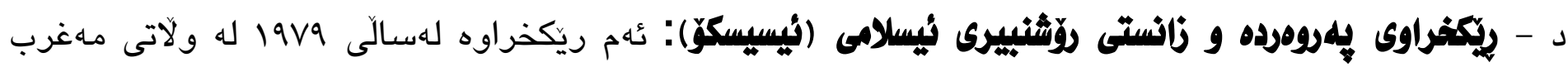

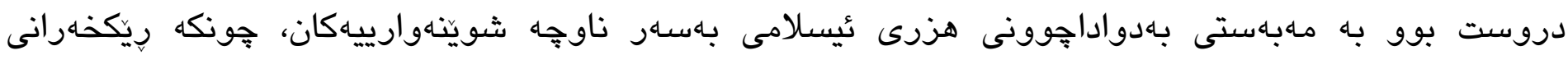

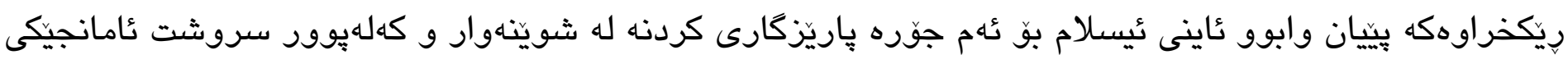

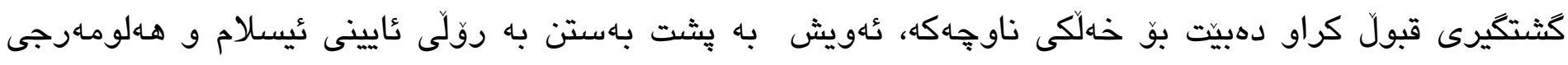

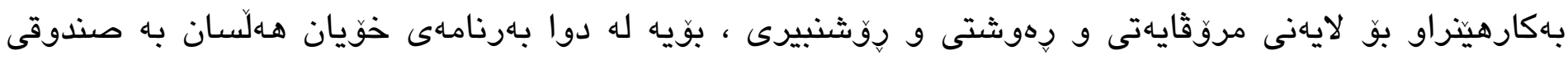

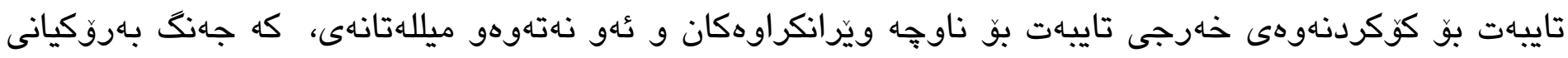

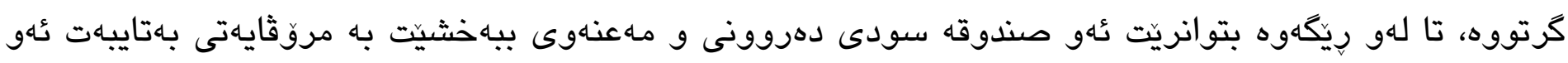

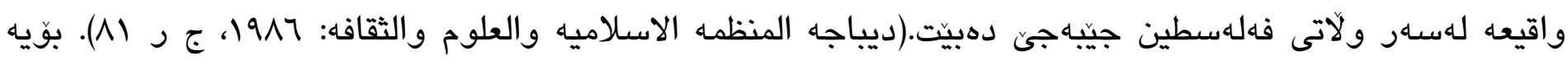

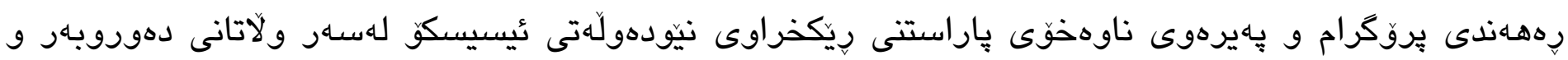

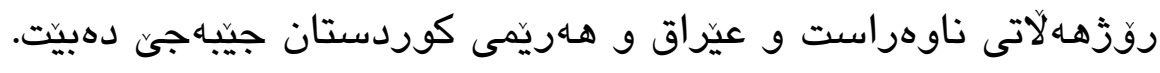




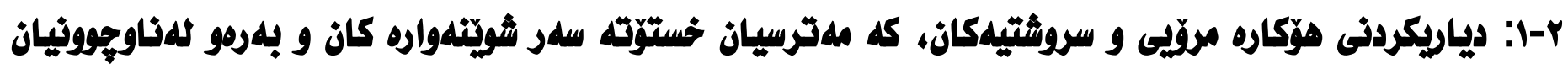

\section{بردووذ.}

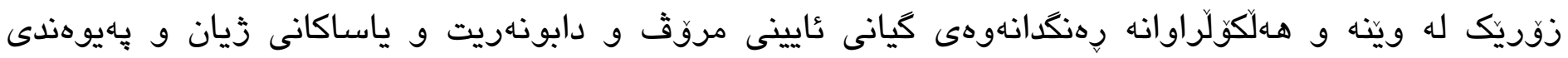

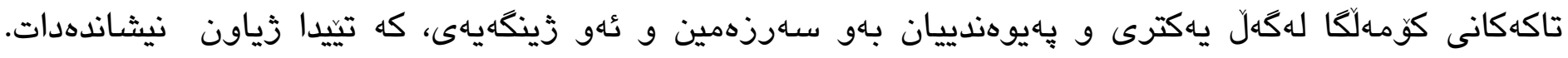

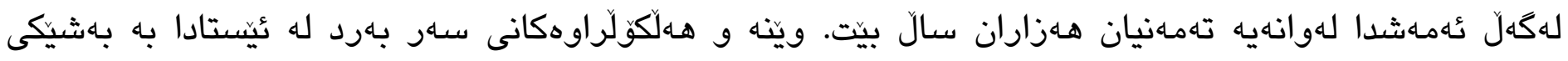

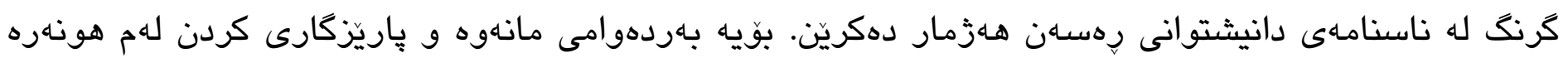

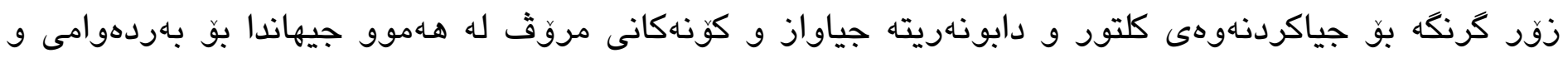

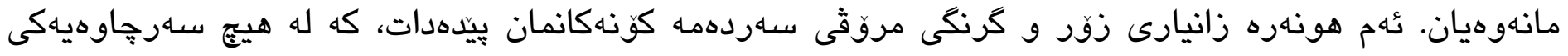

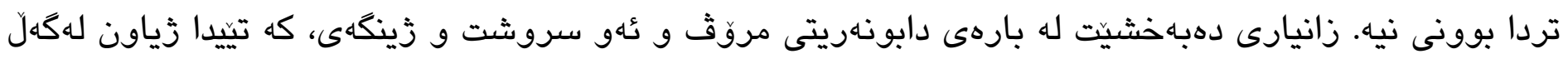

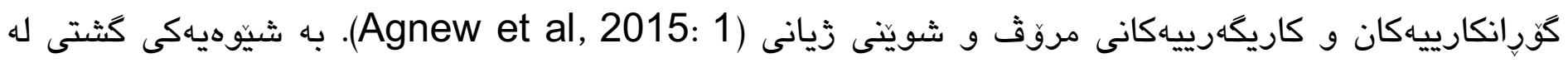

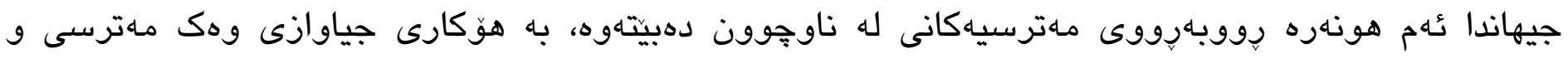

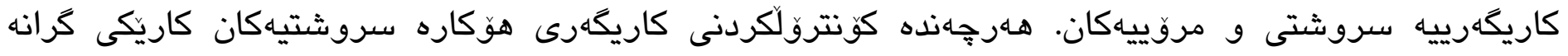

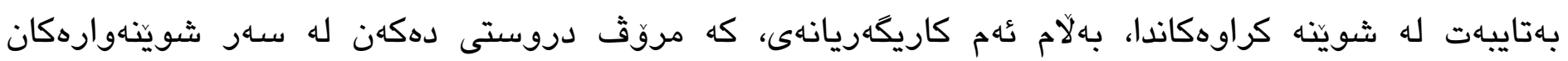

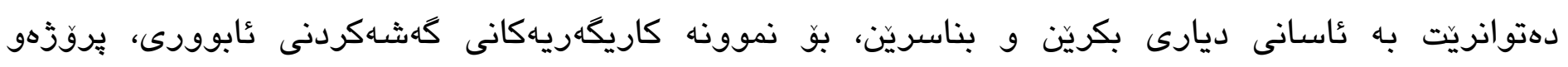

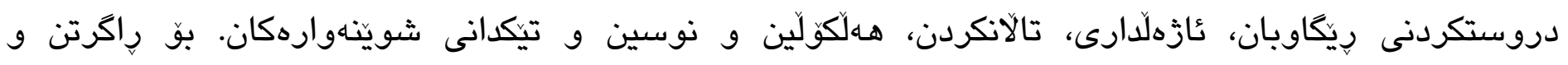

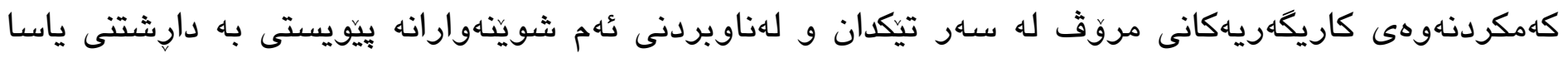

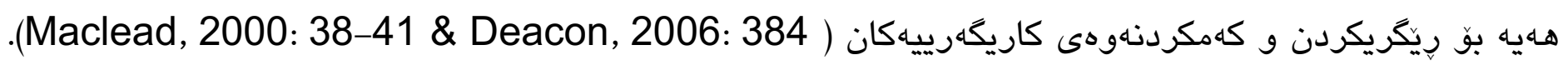




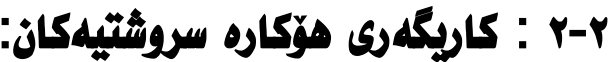

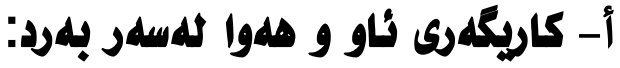

ياكيكه له كاريكارييه راستاوخُ و بهردهوامهكان دهبيته هوَى تيكدان و رووخانى جينى سهاروهى بهرد و

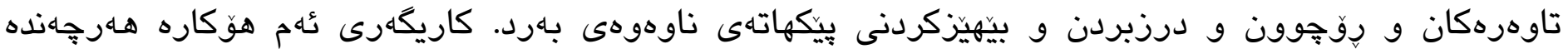
ماوهيهكى زورىى بيّويسته بهلام كاريكهريان لهسهر ئهو بهرد و تاوهرانهى، كه هـلكَّلَينيان لهسهره زياتر دهبينريتي

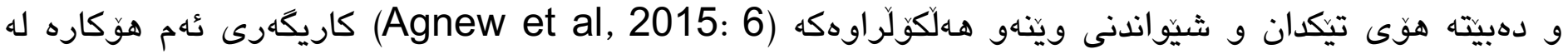

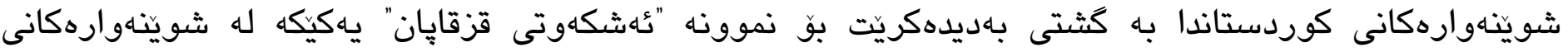
كوردستان و ل70كم له باكورى روزئاواى شارى "سليّمانى"يه و به بهرزى ^م له لإيالى شاخدا دروستكراوه، كه

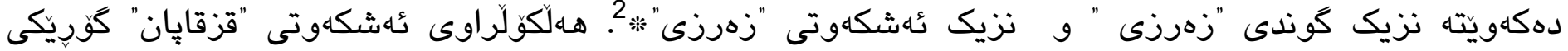

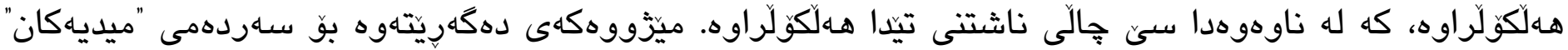

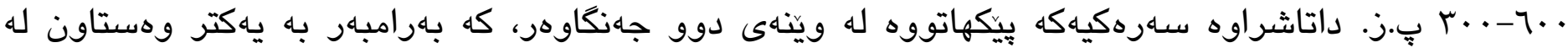

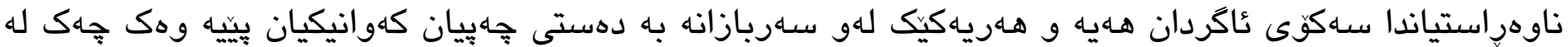
جهنكا بهكاريان هيناوه، دهستى راستيشيان بهرامبهر به يهكتر بهرزكردوتهوه، كه بامازهيه بو سلاّو كردن. جكَه له نهخشه سهرهكيهكه هيمّاى سيّ خواوهند له بهشى سهرهوهى داتاشراوهكه هـلكَّلَّراون، كه به هيمّاى خواوهندى

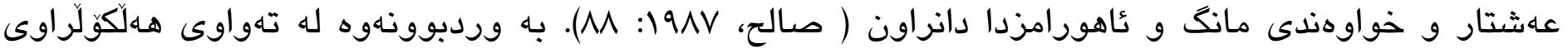

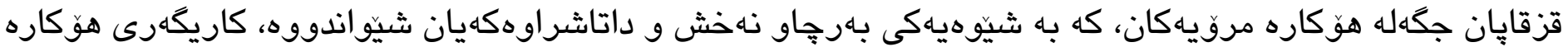

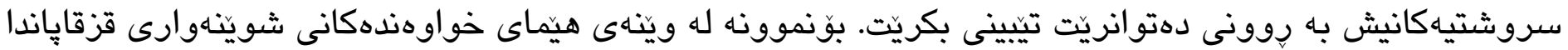

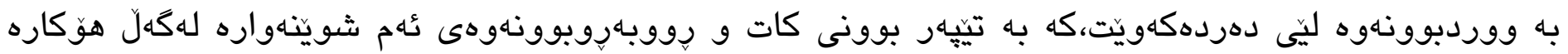
سروشتيهكان كاريكهرى دياريان كردوّته سهار شوينّهاروكه و بوونهته هوَى دروست بوونى درز و كون و كُورانى

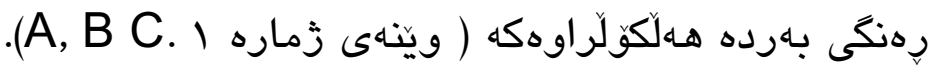



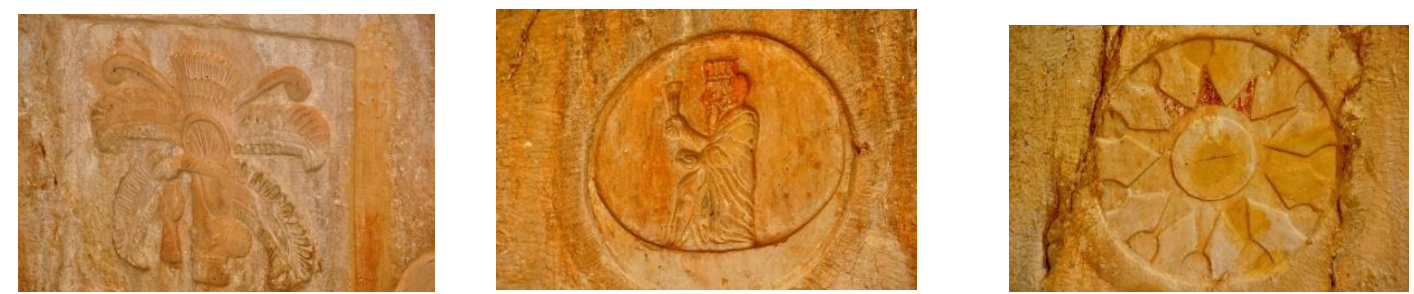

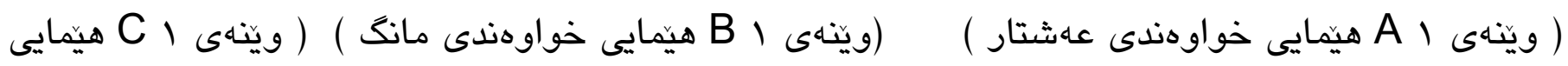

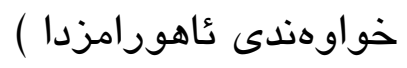

(figure 1 from, Amin, O. S. M, 2018. https://www.ancient.eu/ The Rock-Cut Tombs of Qizqapan, Iraqi Kurdistan: Median or Achaemenid)

\section{ب- كاريكهرى ناوى باران (باراناو) و تهريوون :}

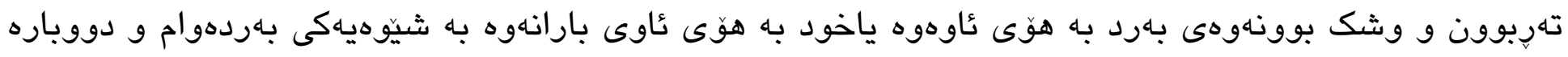

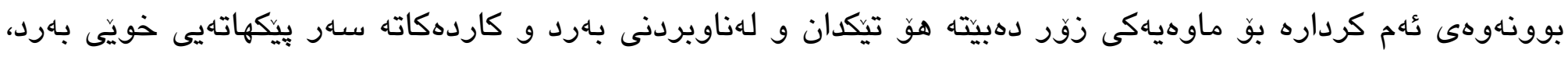

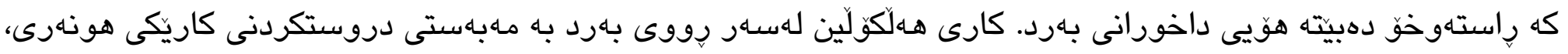

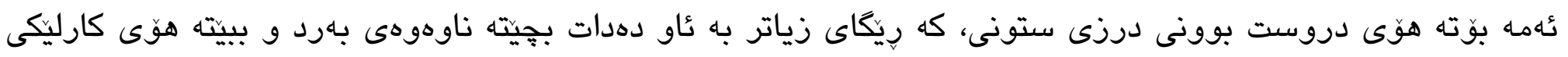

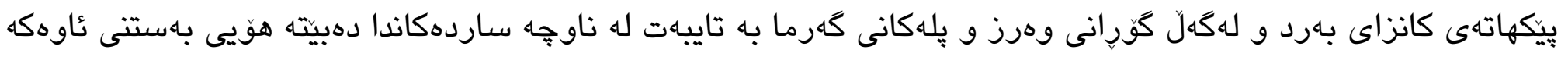

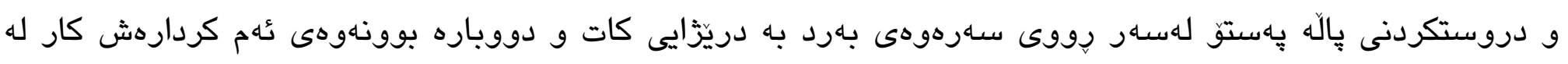

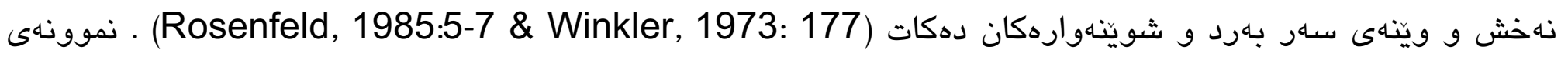

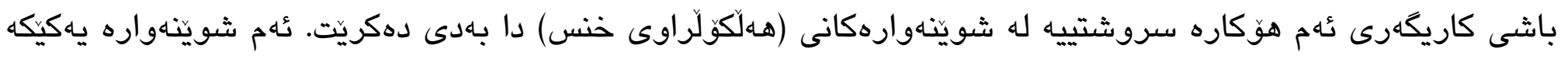

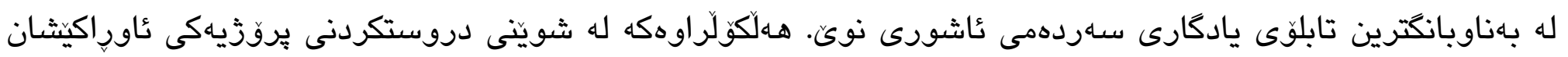

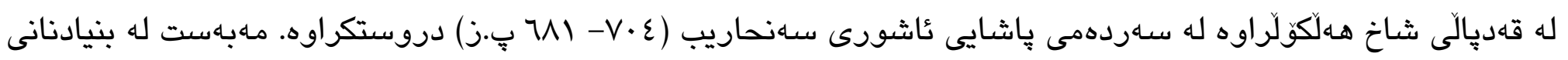

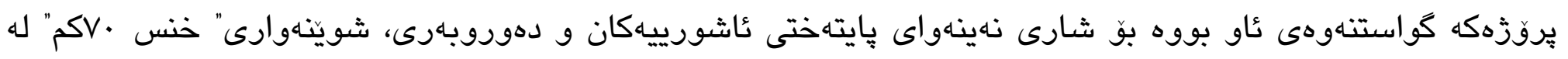

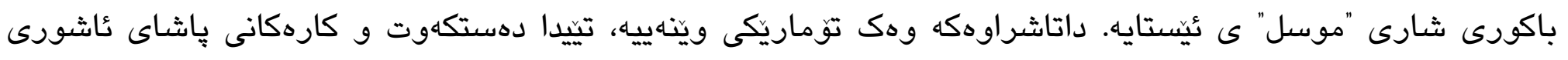

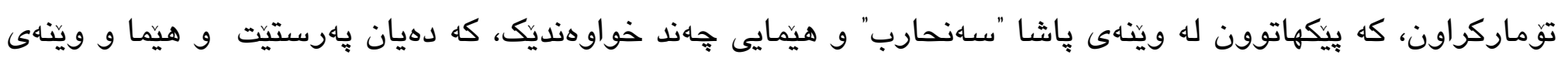




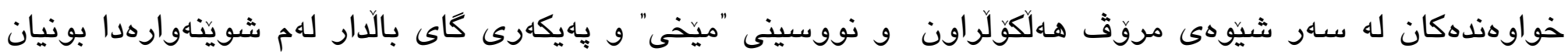

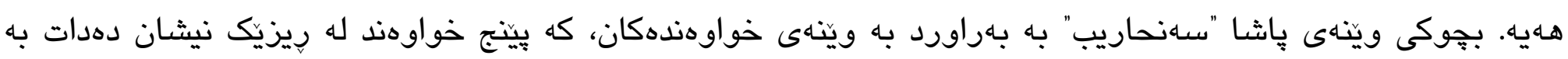

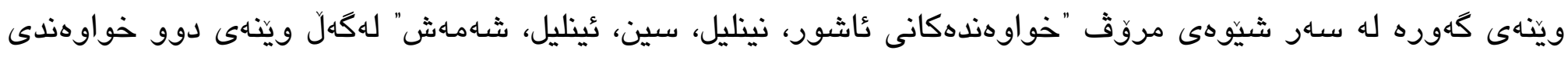

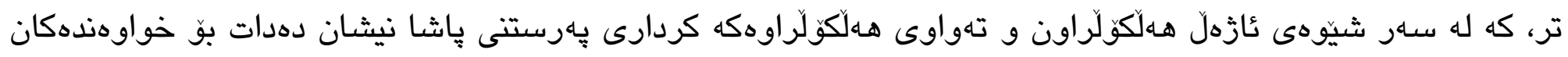

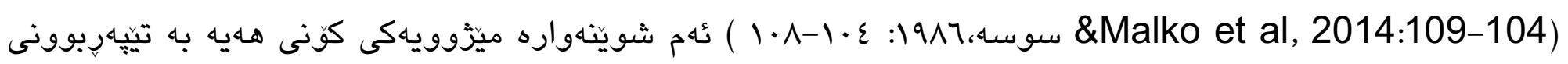

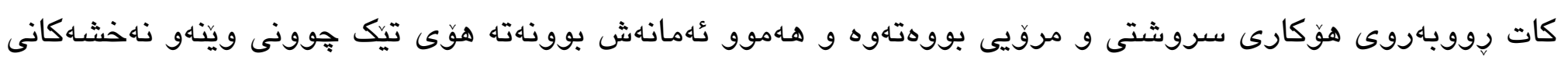

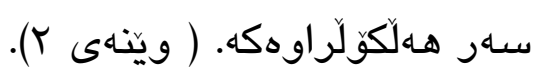
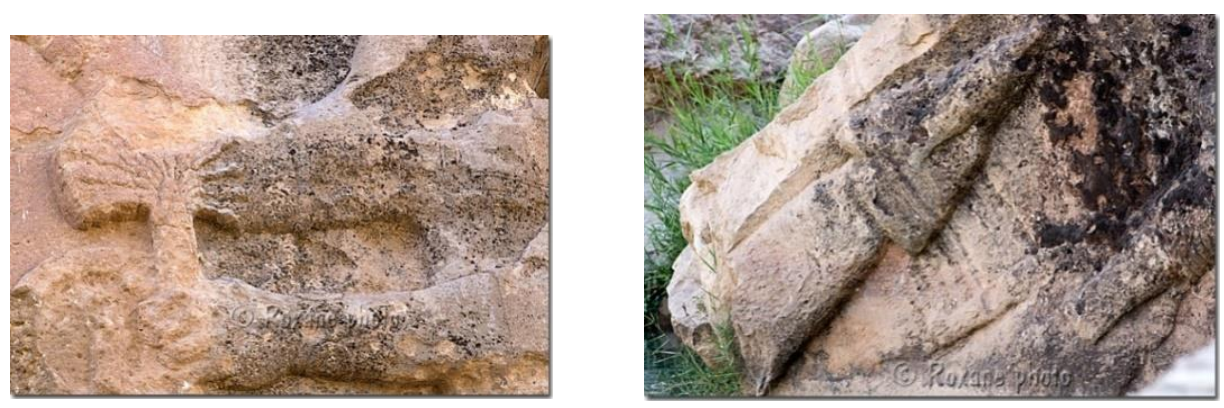

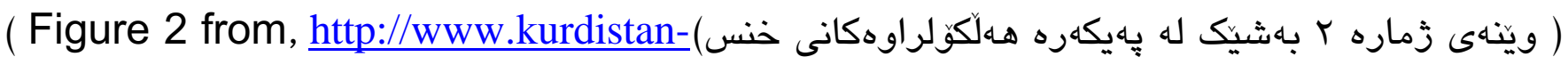
photos.com/cache/khenis/)

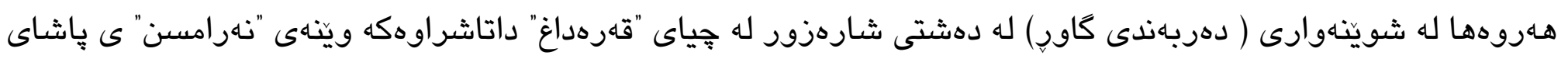

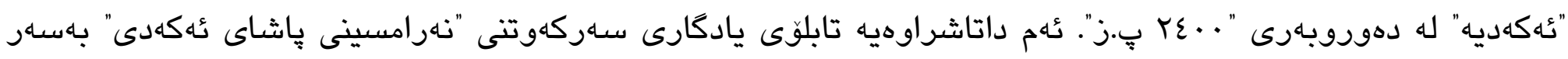

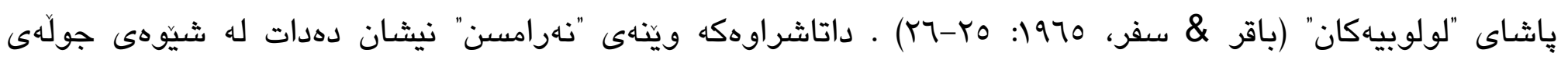

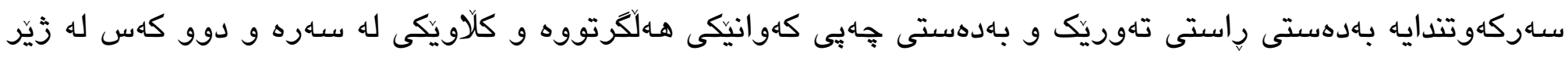

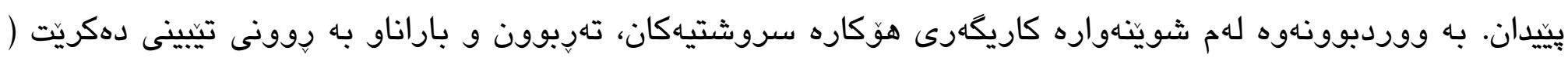
وينّاءى زماره بان. 

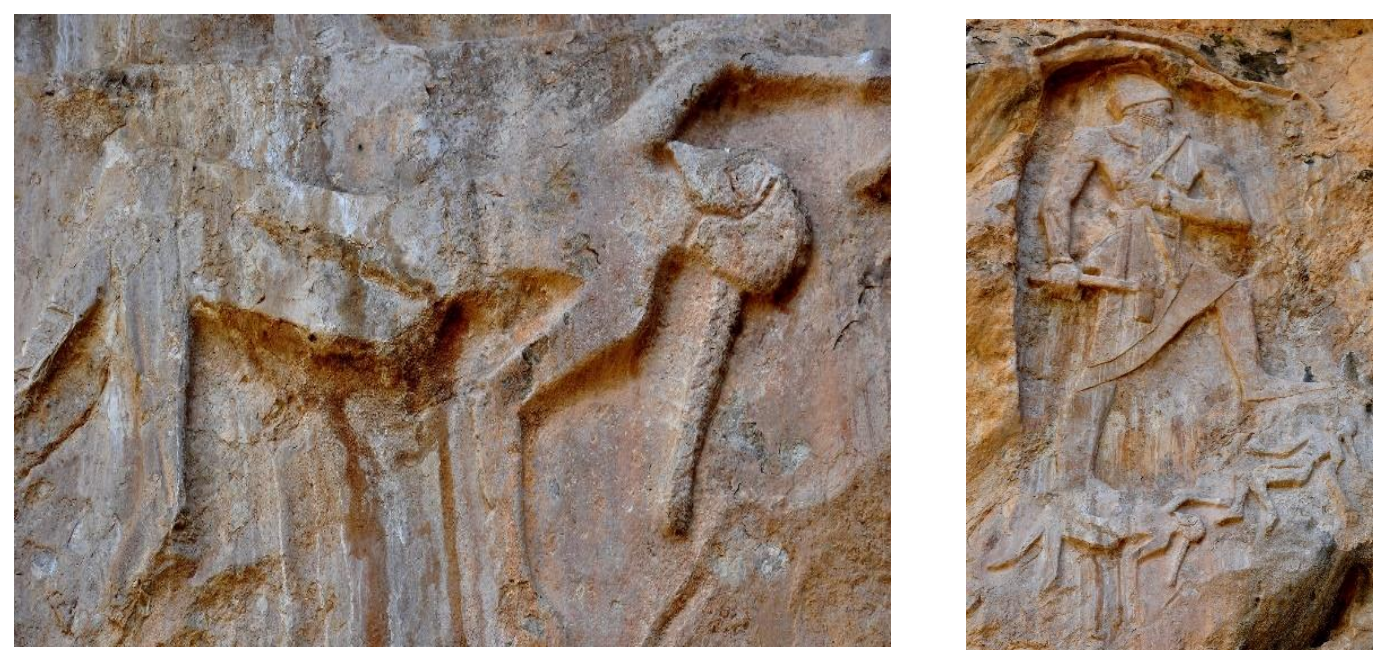

(Figure 3 from, Amin, O. S. M, 201. (وينّى زماره r هـلكَلَّاوى دهربهندى كاور) http://etc.ancient.eu/travel/naram-sin-relief-iraq/ )

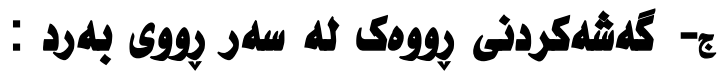

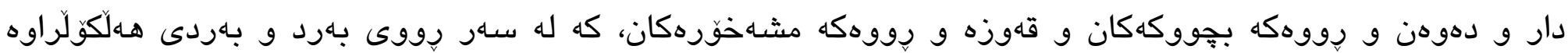

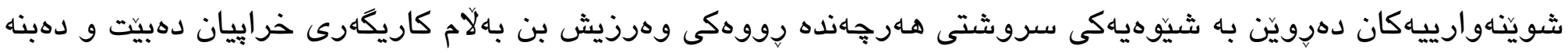

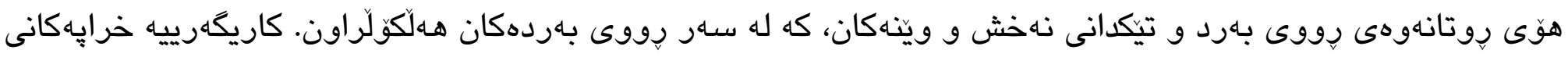

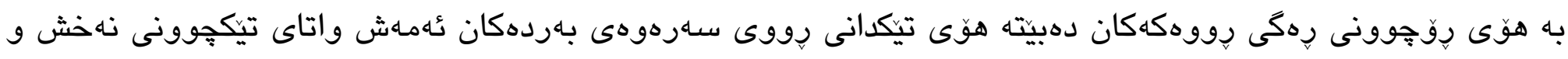

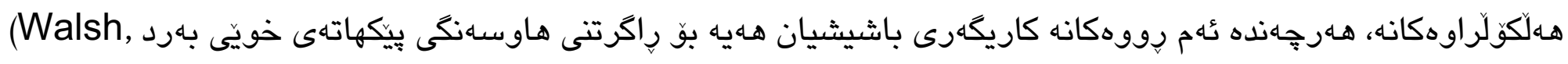

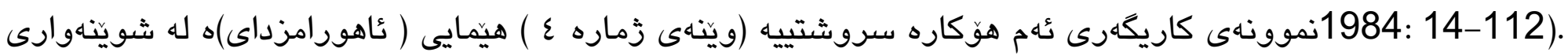
ئكاشكهوتى قزقابان. 


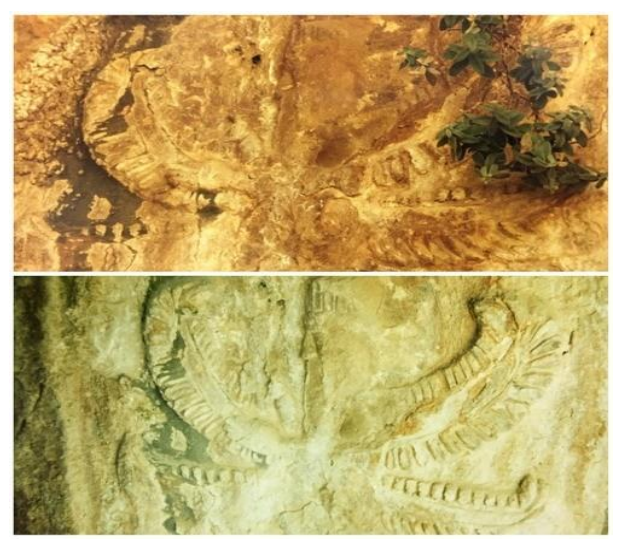

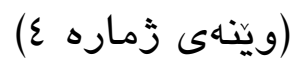

(figure from, 4 from Amin, O. S. M, 2018. https://www.ancient.eu/ The Rock-Cut Tombs of Qizqapan, Iraqi Kurdistan: Median or Achaemenid)

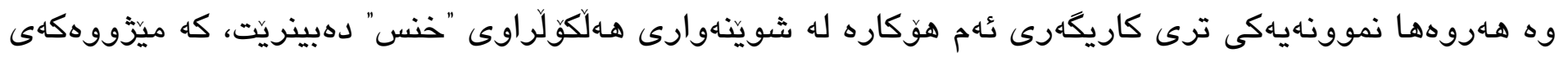

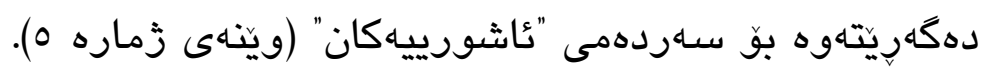
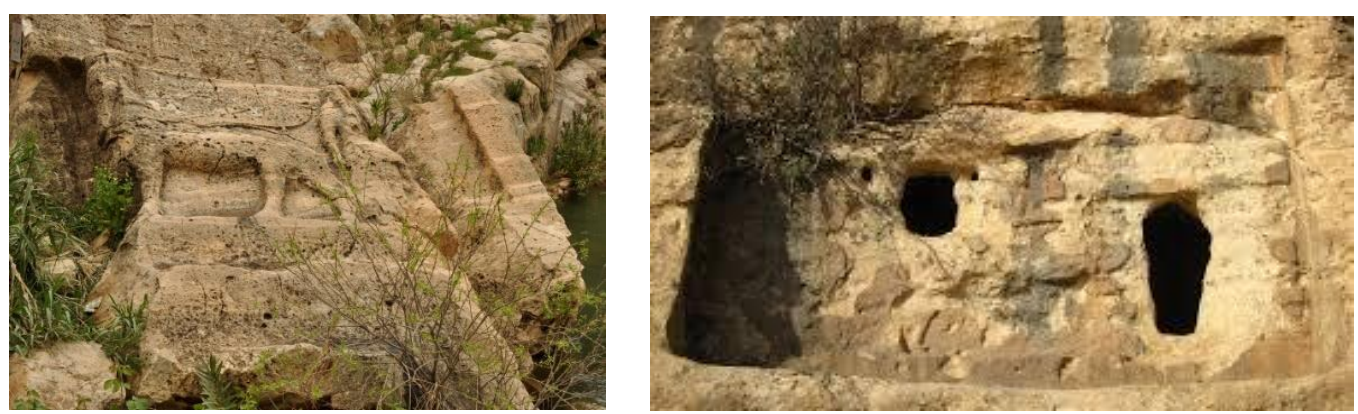

( Figure 5 from, (وينّاء زماره ه ) نموونهى داتاشراوهى خنس كه كاريكهرى هؤكارى سروشتى نيشاندهدات ) http://www.kurdistan-photos.com/cache/khenis/ )

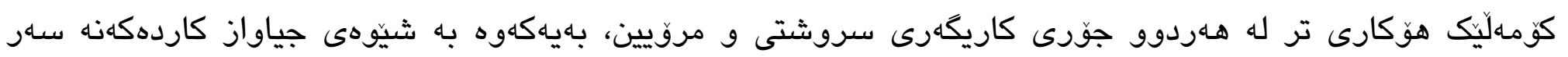

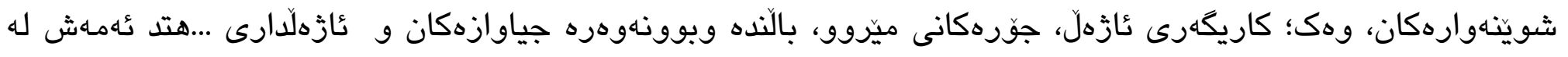

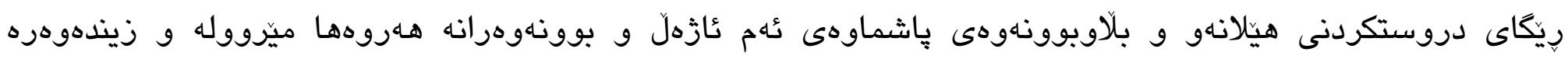

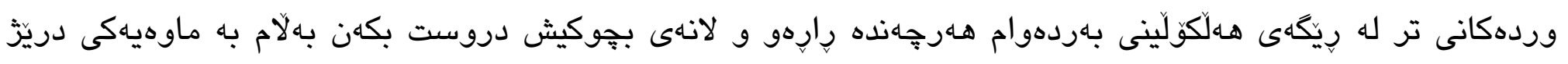

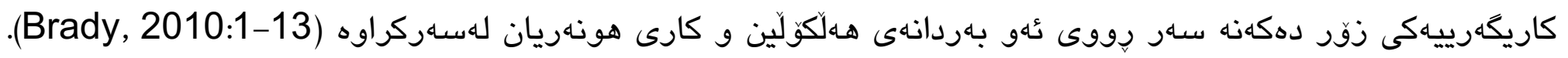

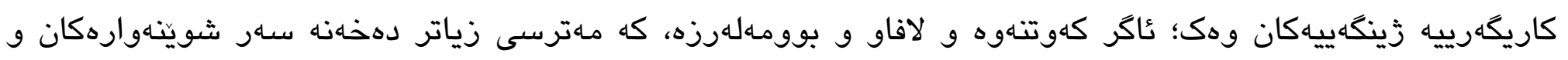

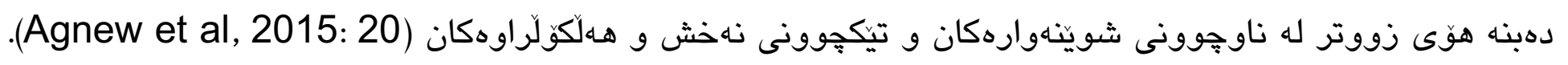




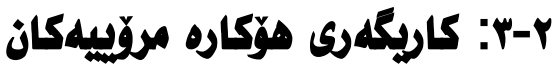

\section{أ- نوسين و تيكدانى ثموينهوارمكان:}

نووسين و تيكدانى شويناهواردكان جهند شيّوهيهكى ياوازتريش له خوّى دهكريّت له سهرتا سهارى جيهاندا، كه به

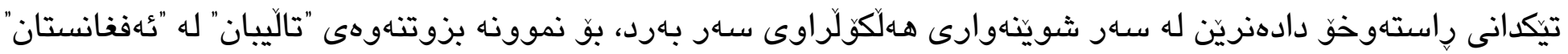

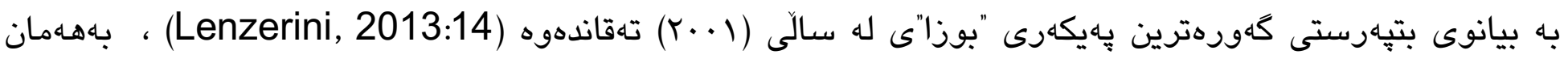

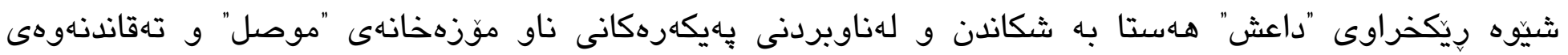

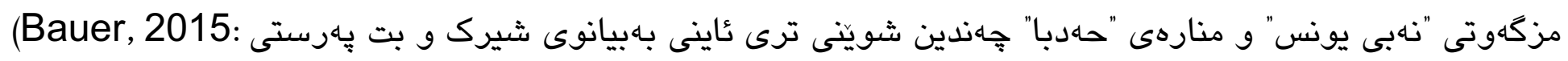

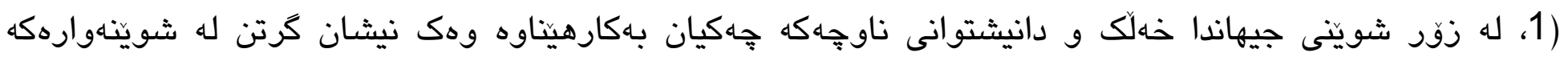
ئهماش دهبيته هوَى تيكدان و سرينهوهى شويناهوارهكه، بههامان شيّوه له كوردستانيش به ورد بوونهوه له رووىى

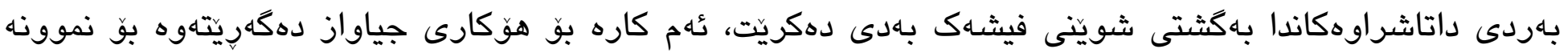

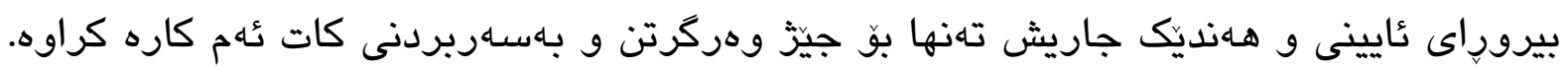

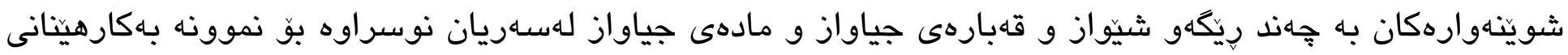

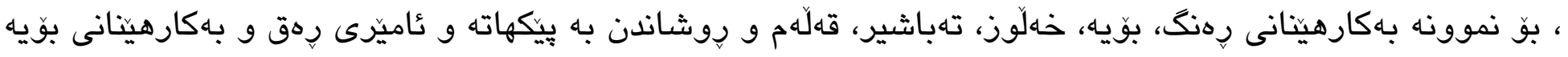

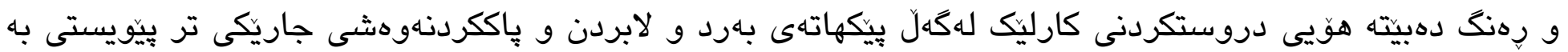

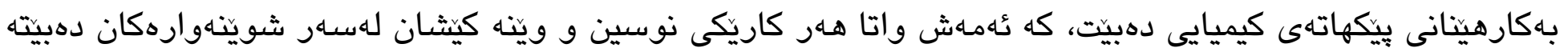

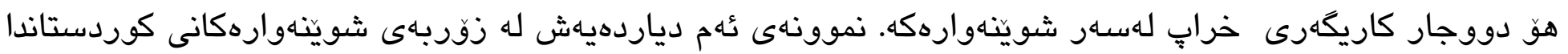

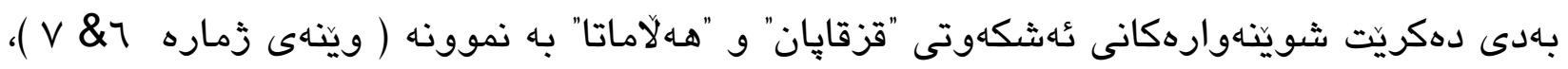
.(Lambert, 1989: 10-40 \& Fernandes, 2009: 729-32)
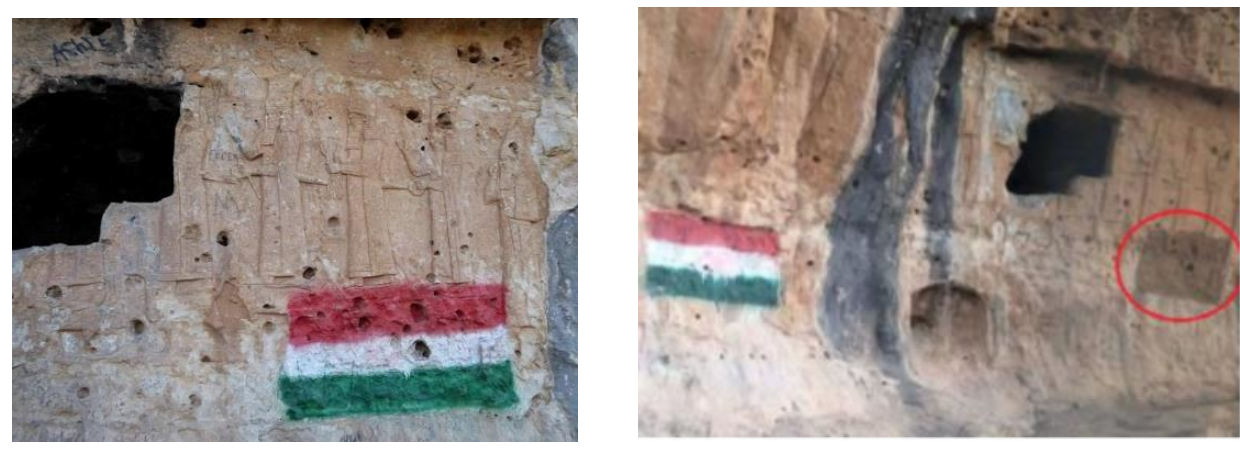

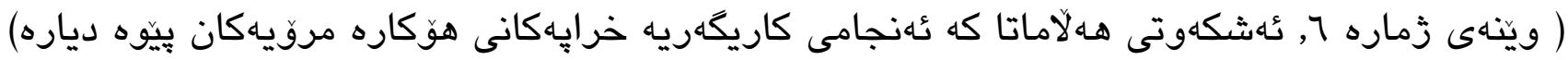

(figure 6 from, Hanna.R \& Barber. M, 2017. Page 54) 

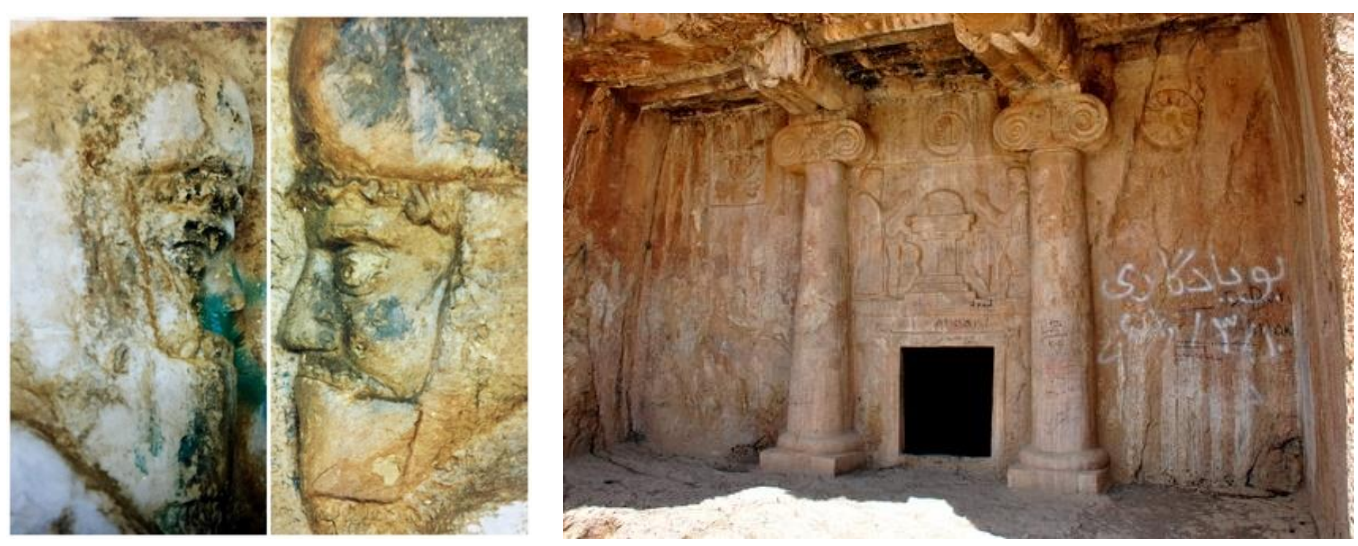

( وينّاهى زماره V , عاشكهوتى قزقايان كه عُهنجامى كاريكهريه خرايهكانى هوَكاره مروّيهكان بيّوه دياره)

(figure 7 from, Amin, O. S. M, 2018. https://www.ancient.eu/ The Rock-Cut Tombs of Qizqapan, Iraqi Kurdistan: Median or Achaemenid)

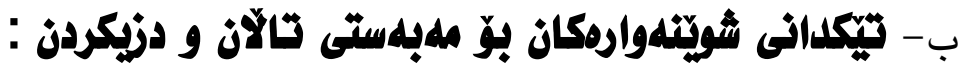

به تالان بردن و تيكدانى شويناهوارهكان و دواتر بهكارهينانيان بو بازركانى كردن به شيّوهى ناياسايى، هوَكاريكى

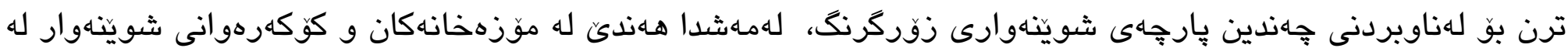

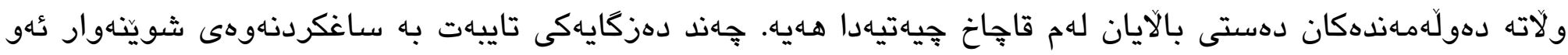

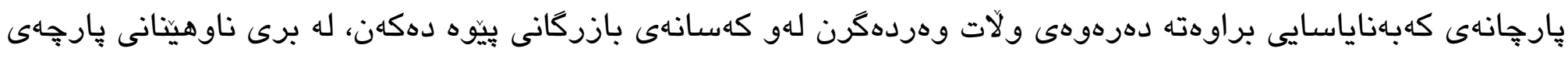

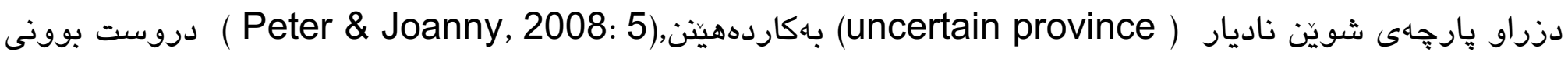

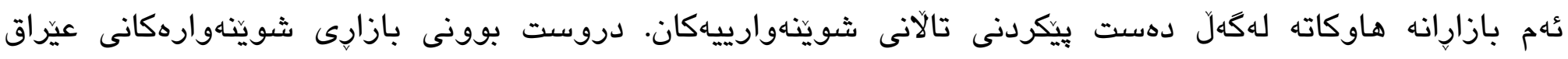

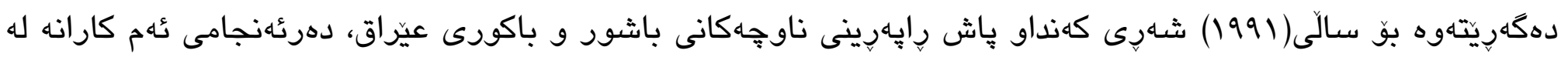

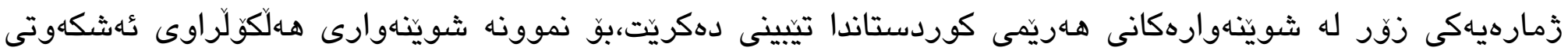

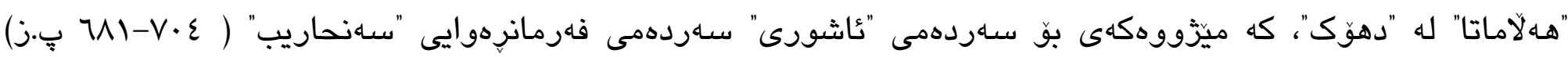

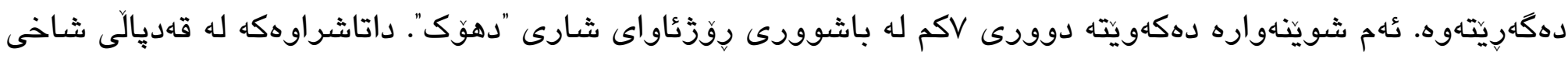

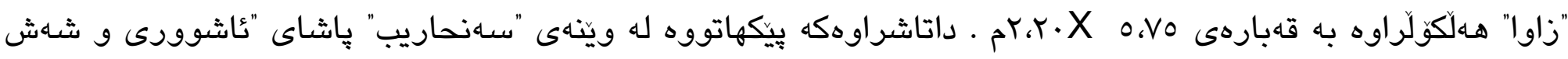

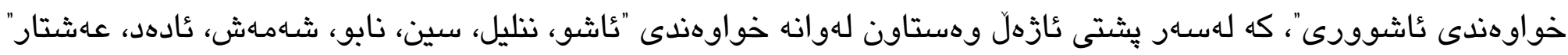

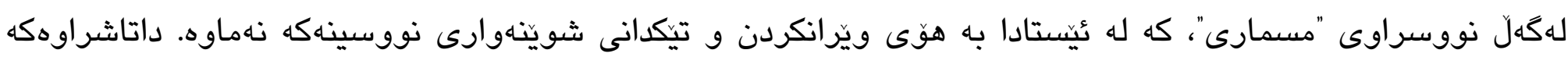

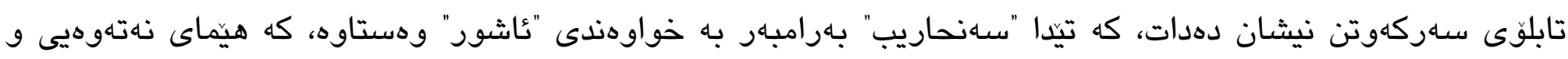




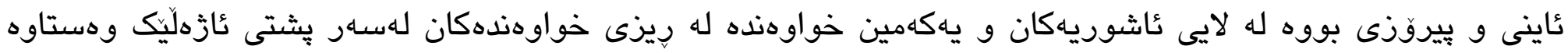

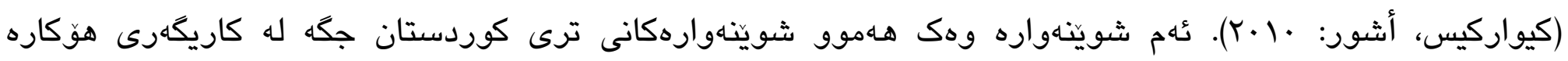

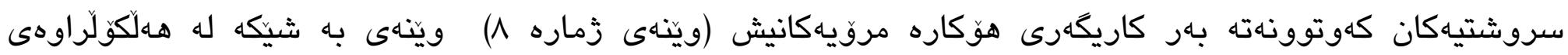

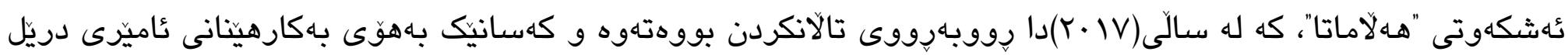
هيماى خواوهندى ناشوريان دهرهيناوه.
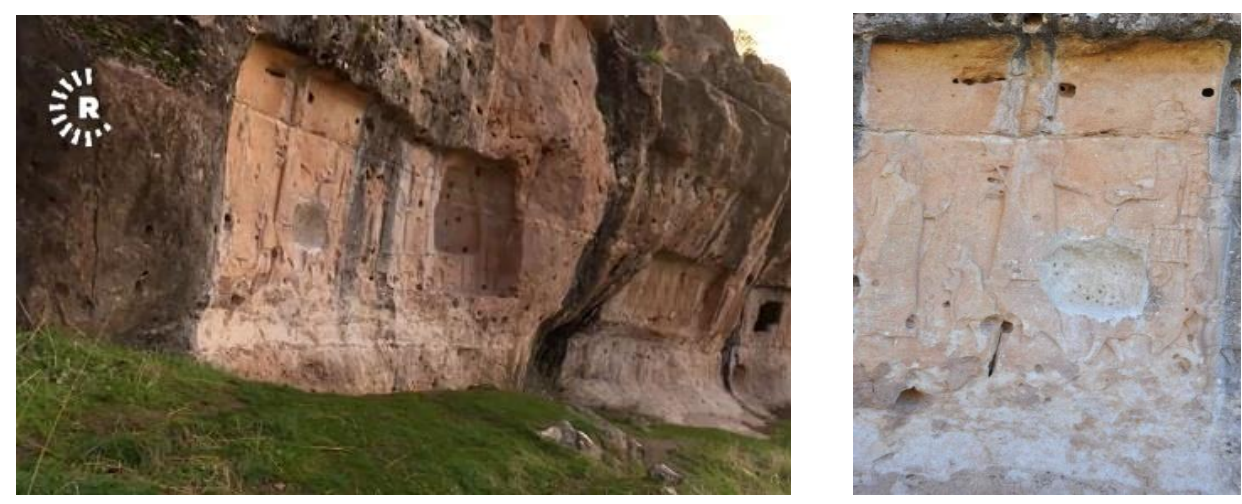

(ويّنهى زماره ^ شوينّاهوارى ئهشكهوتى هـلاّماتايه كه كاريكارى هوَكاره مروّيهكان نيشاندهدات)

(figure 8 from, Nasr. A, 2018. http://www.rudaw.net/english . Thieves raid 2700-year-old site in Duhok)

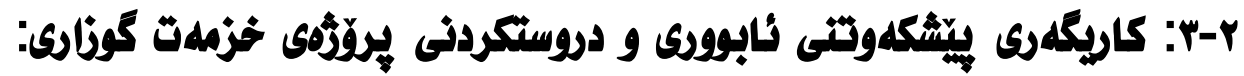

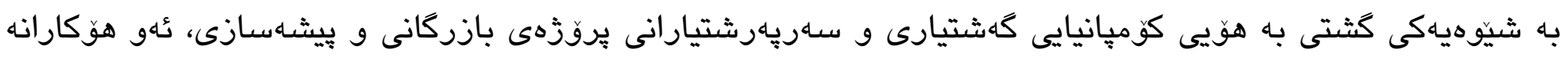

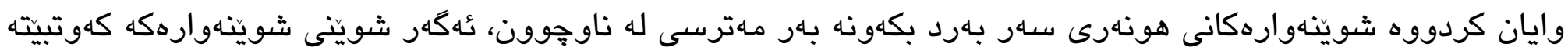

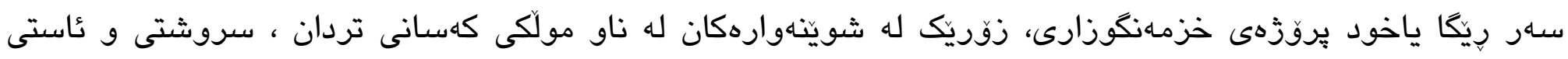

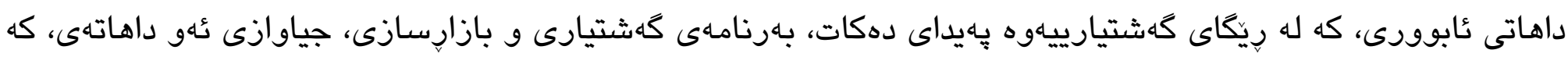

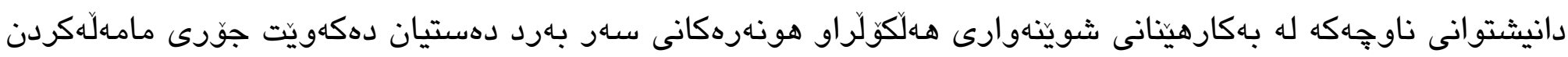

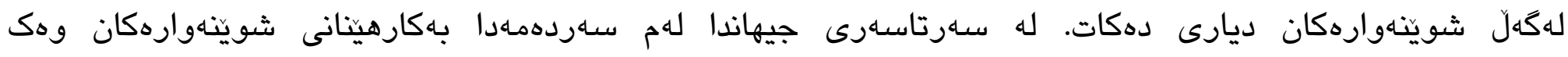

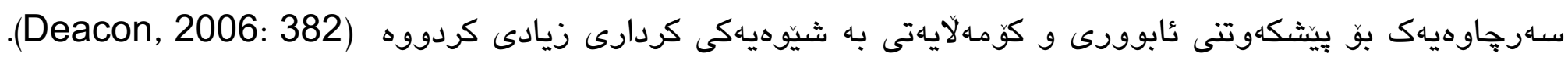

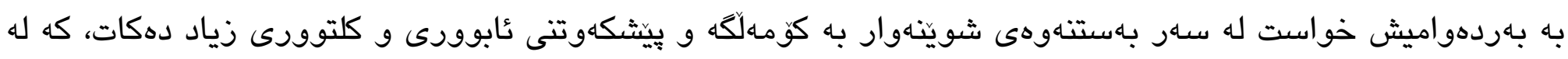

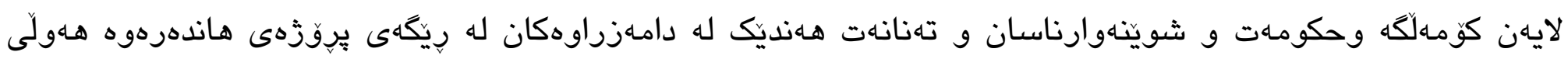

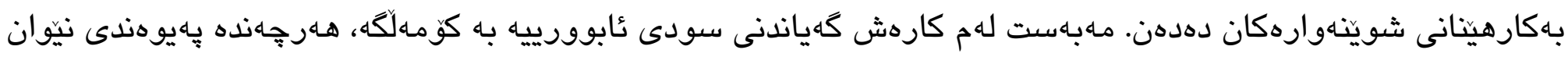




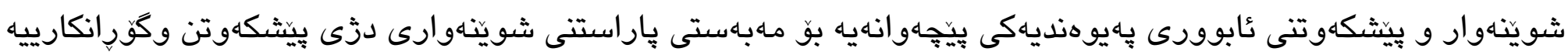

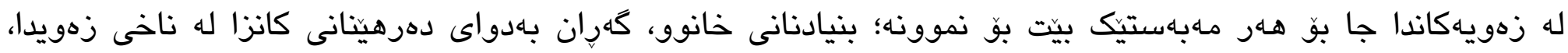

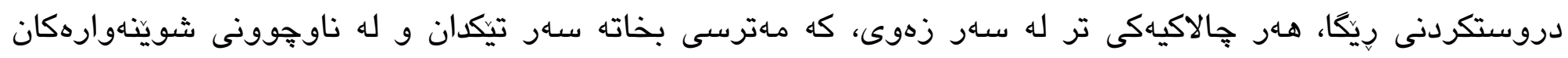

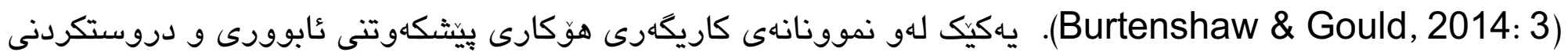

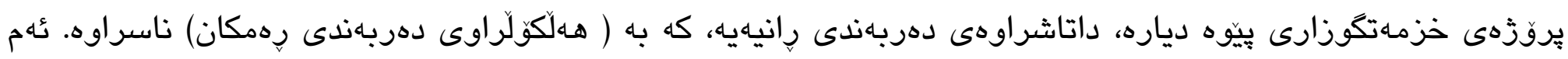

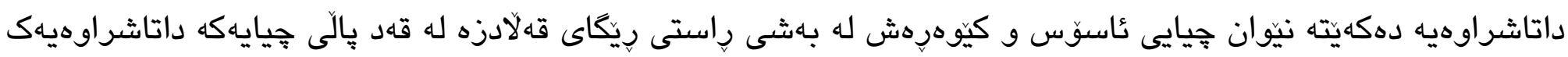

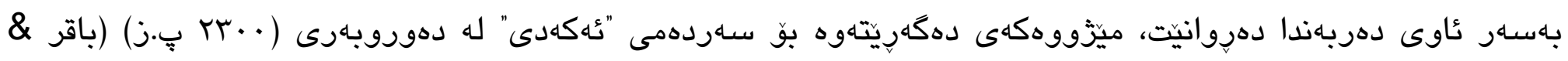

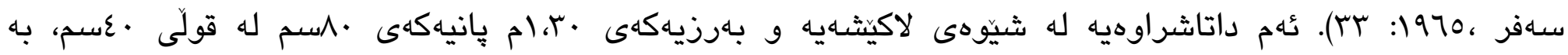

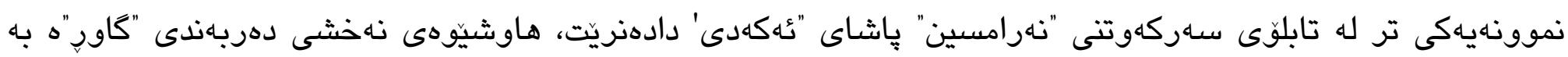

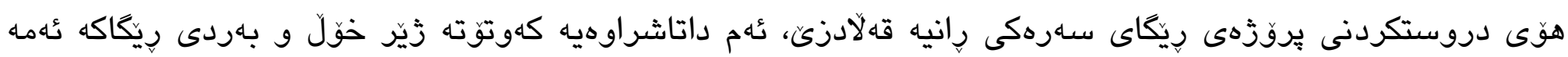

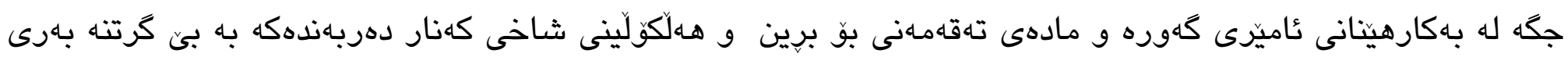

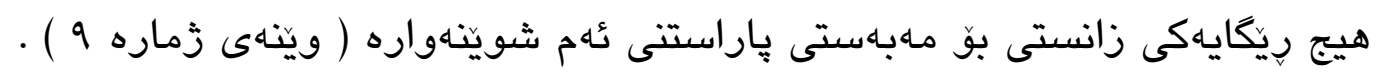
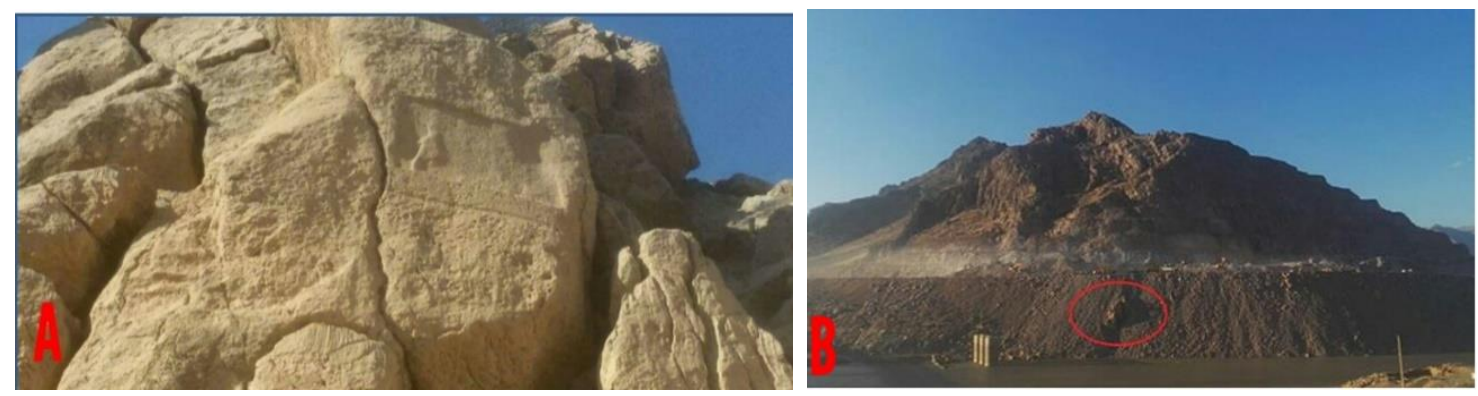

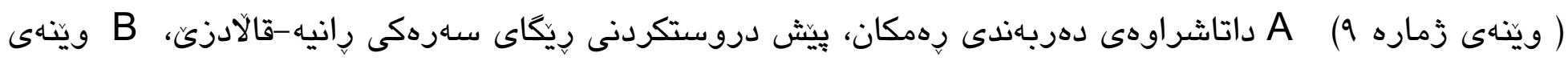

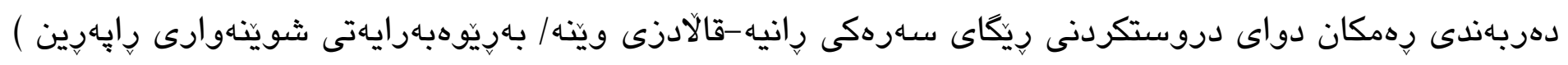




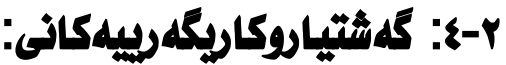

كهشتياران به شيّوهى جياواز كاردهكهنه سهار شوينّاهوارهكان بههوَى جولَه و هاتوجوَكردن بهسهرياندا و بهكارهينانى

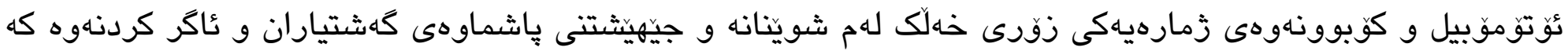

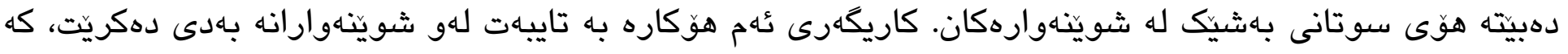

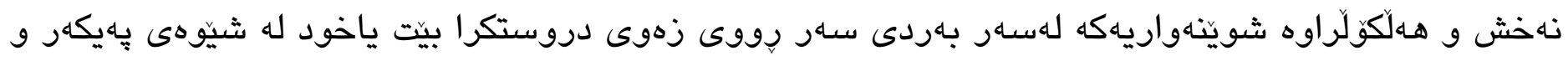

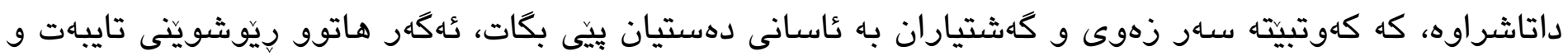

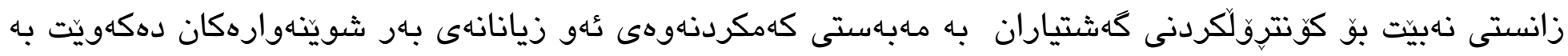

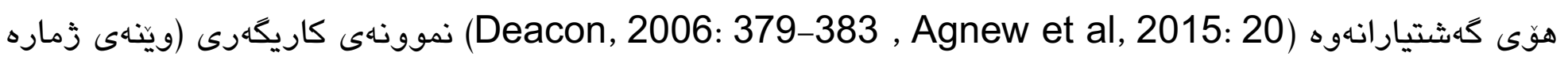

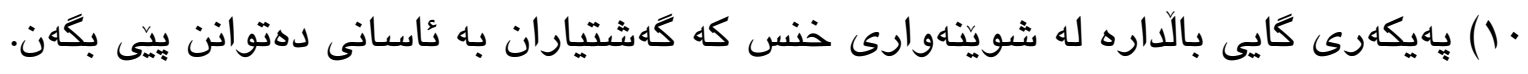

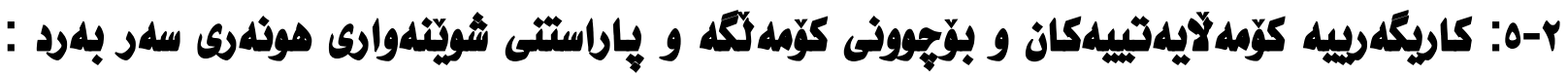

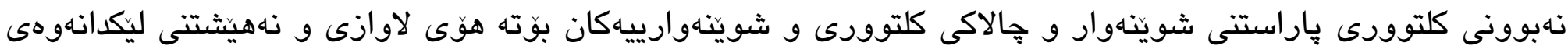

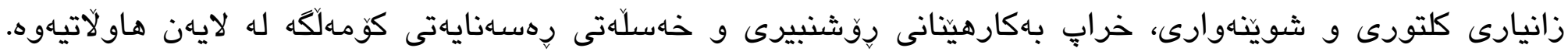

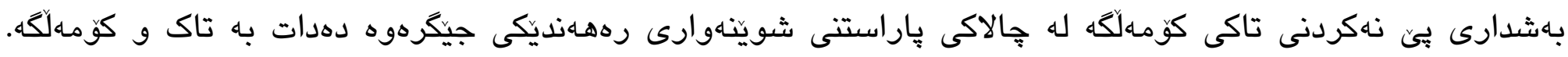

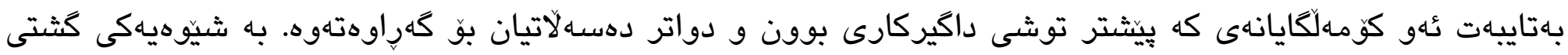

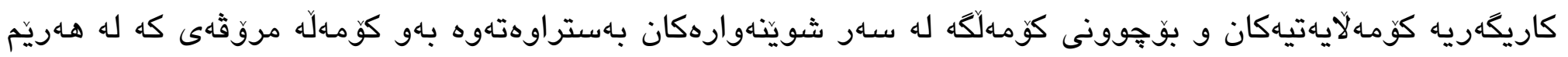

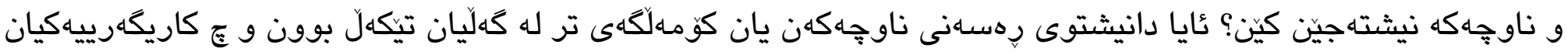

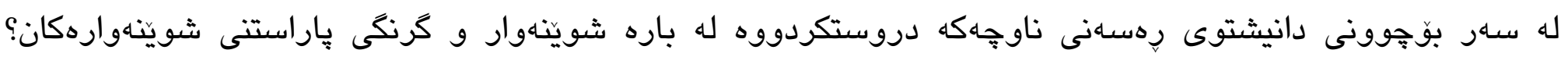
.(Pwiti \& Chirikue, 2008: 476) 


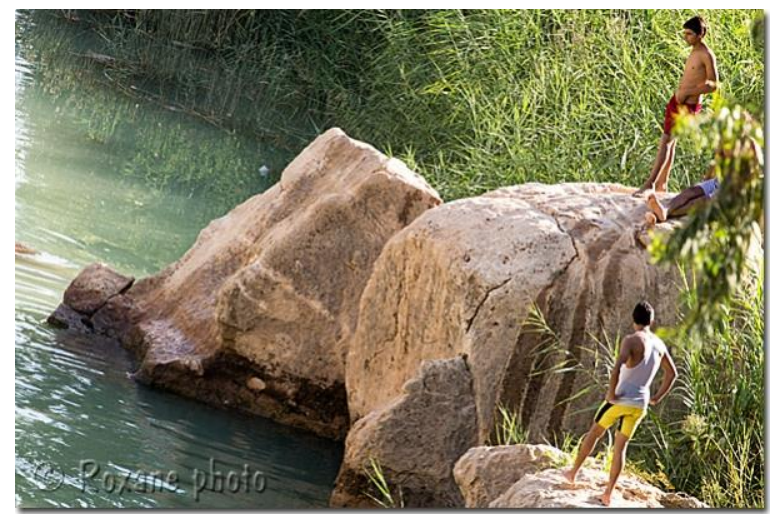

(figure 10 from, http://www.kurdistan-(وينّهى زماره • ا كايى بالدارى شوينّهوارى خنس) photos.com/cache/khenis/

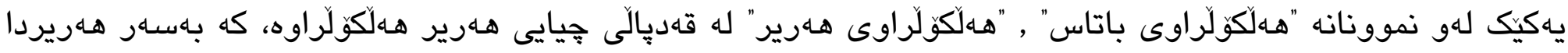

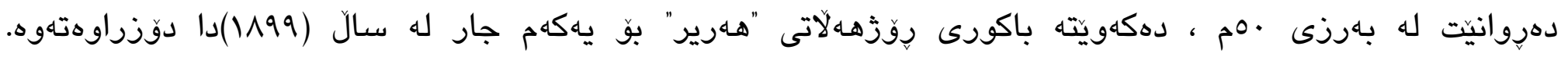

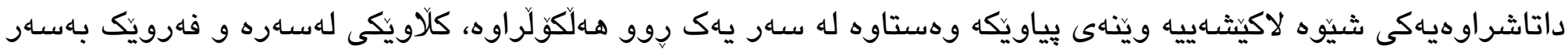

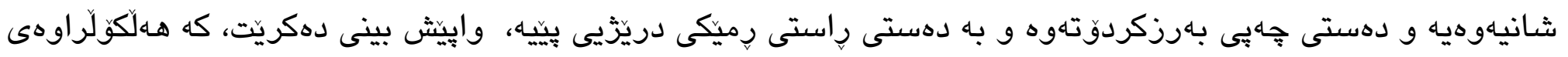

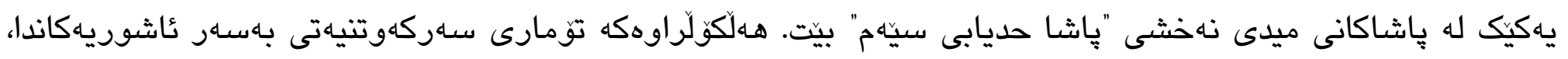

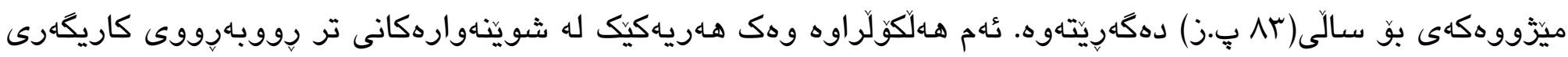

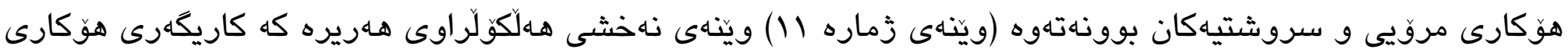

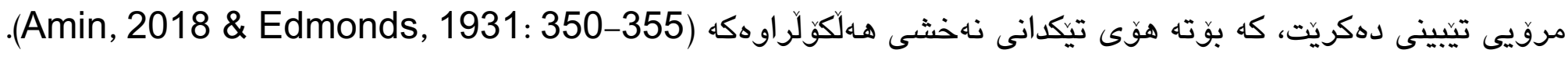



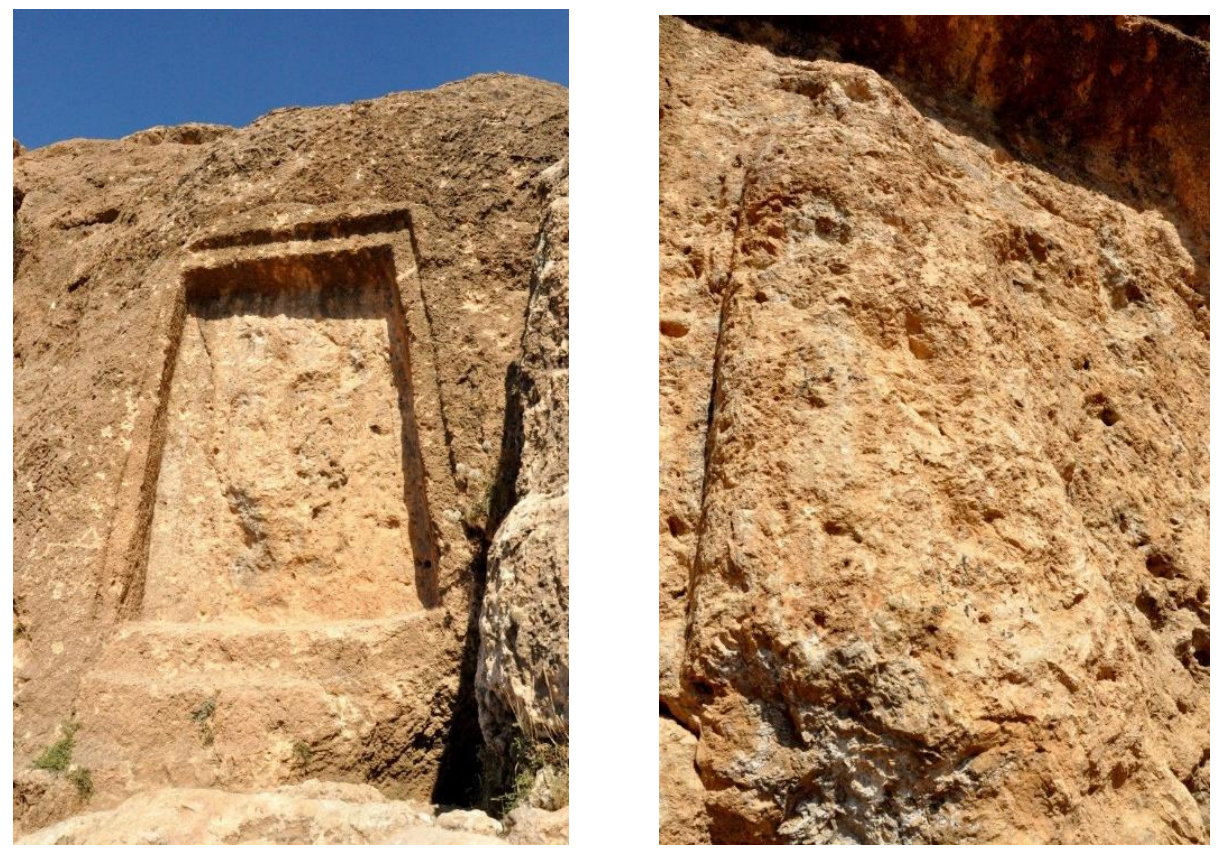

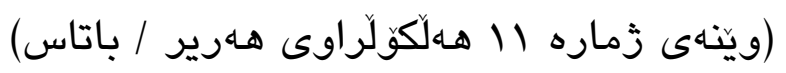

(figure 11 from, Amin, O. S. M, 2018. https://www.ancient.eu/ The Rock Relief of Harir (Hareer), Iraqi Kurdistan)

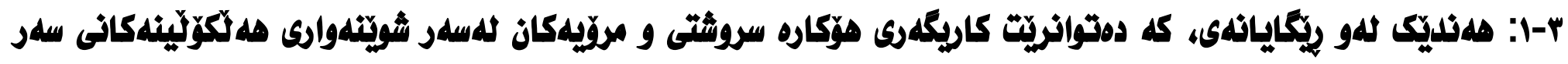

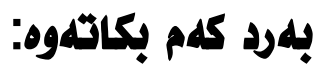

كاريكهرى هؤكاره سروشتييهكان به جهند بيكايهك دهتوانريت كهمبكريتهوه، بو نموونه يهكيك له بريكاكانى

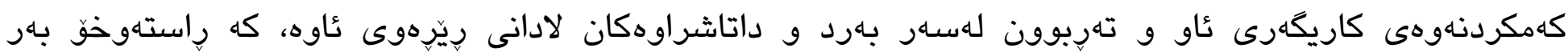

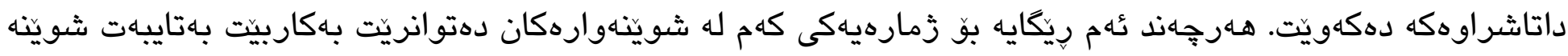

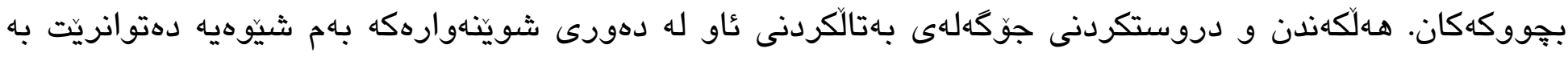

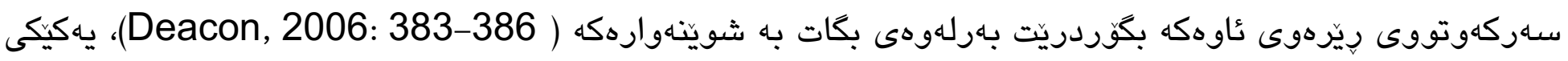

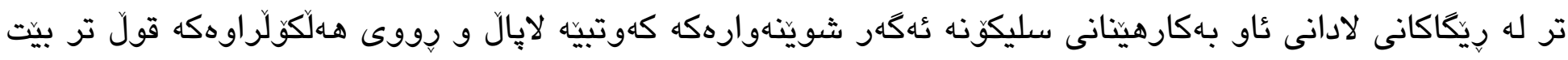

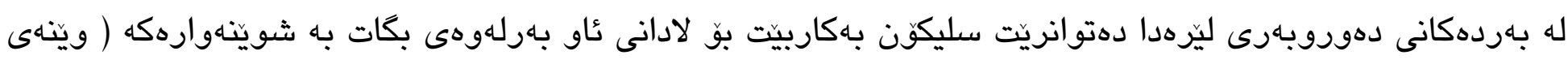

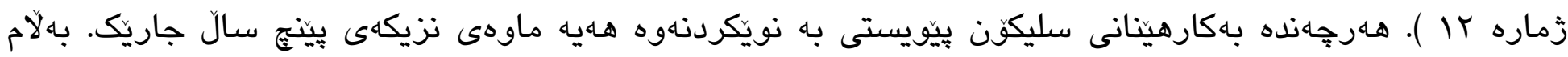

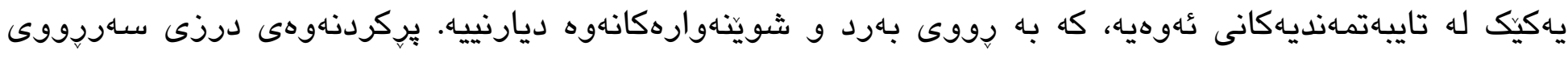

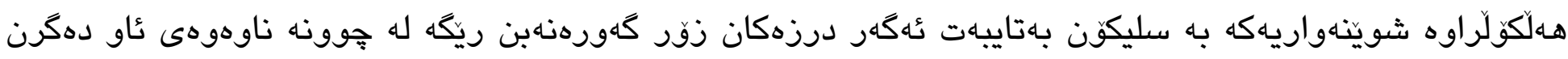




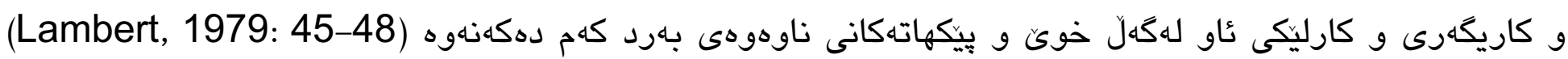

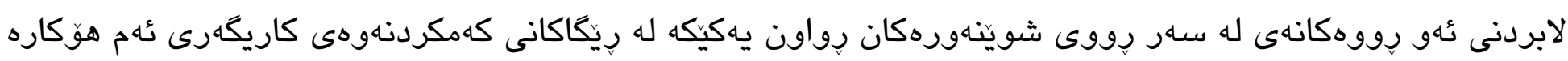

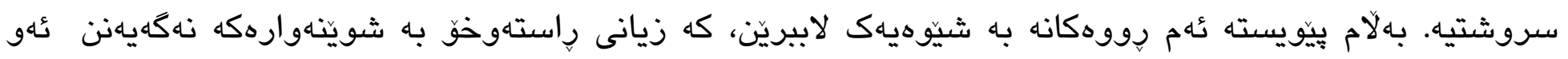

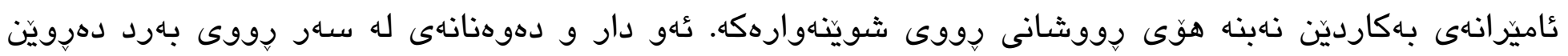

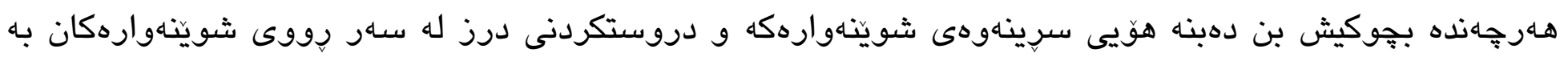

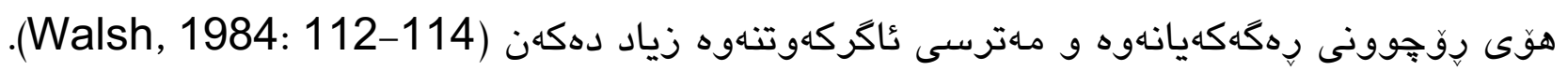
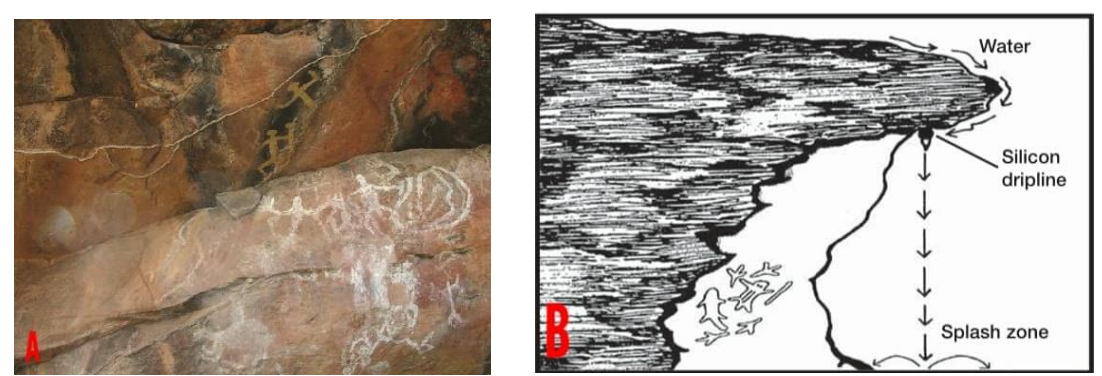

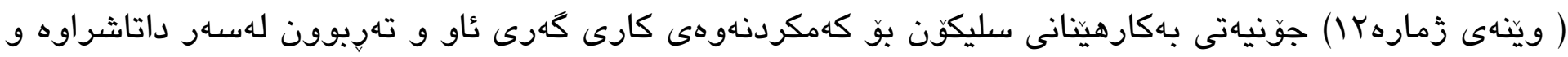
وينّاهى سـار بهارد)

(figure 12 A from, Agnew et. al. 2007. Page 18. Fig 13 B from Lambert. D, 2008. Page 22)

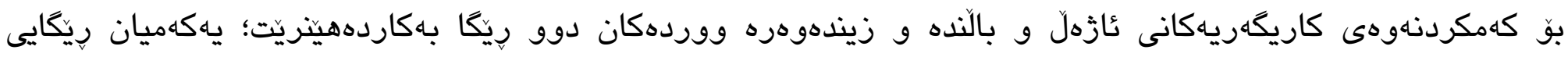

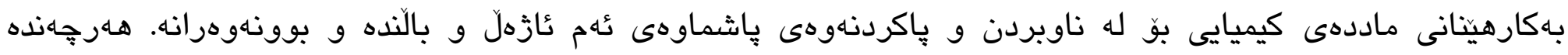

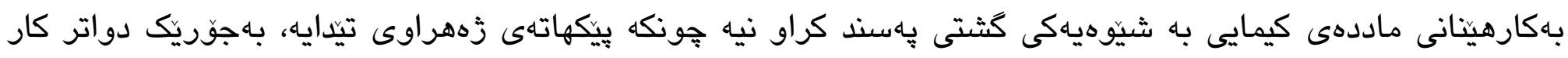

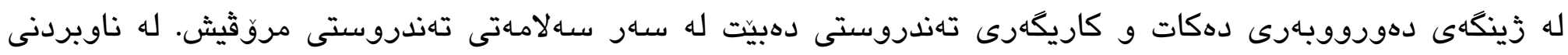

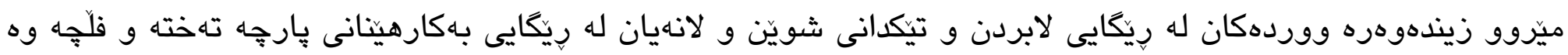

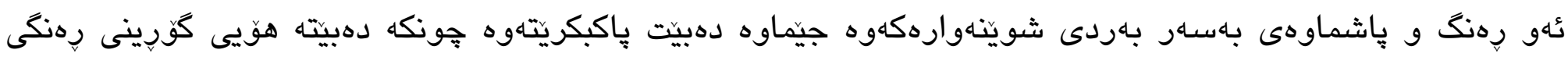

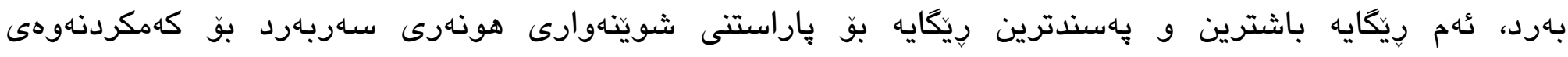

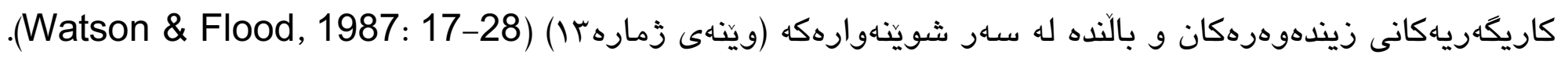



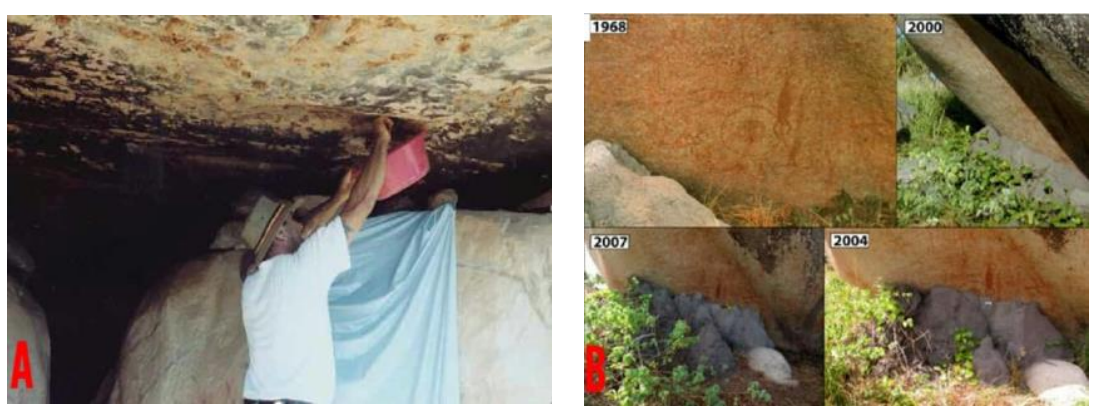

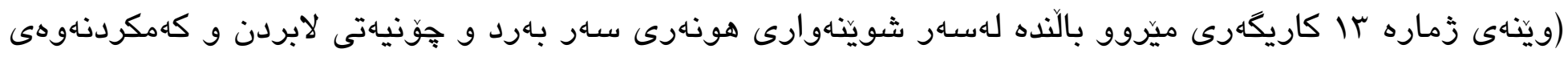
كاريكهريهكان)

(figure 13 A from, Lambert. D, 2008. Page 36. Fig 13 B from, Bady, L. M. et. Al. 2010, 5)

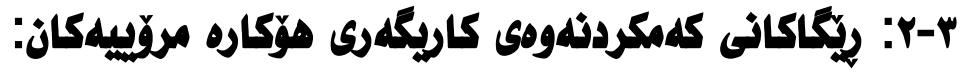

يهكيك له كاريكَهرترين هوَكاره مروّييهكان له سهر هونهرى سهار بهرد و شويناهوارهكان نوسين و تيكدانى شوينّهوارهكان

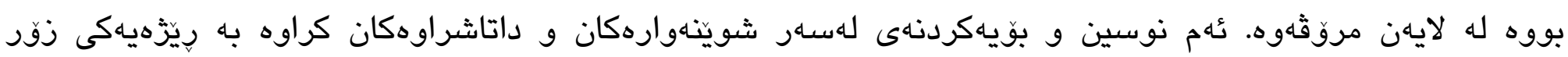

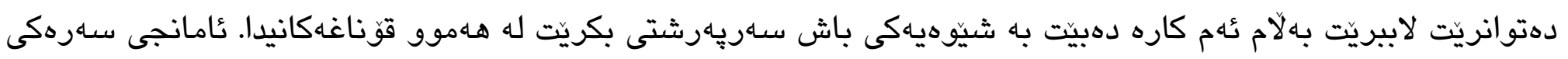
له سرينهوه و لابردنى نوسين و بوّيهكردنهان بق كهم كردنهوهى كاريكهرييه بينراوهكان و و كهمكردنهوه و و

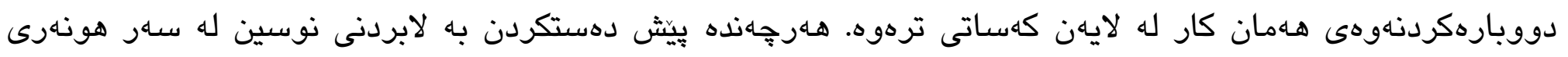

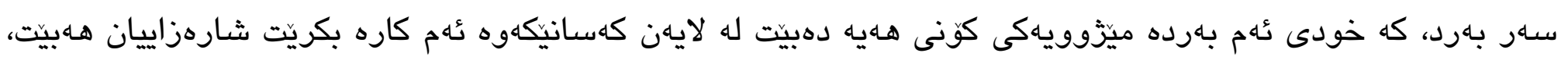

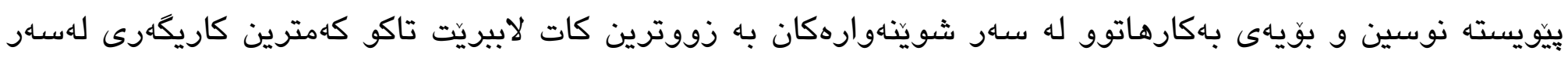

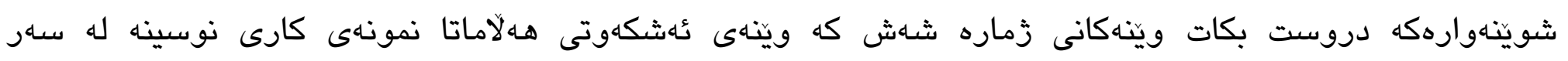

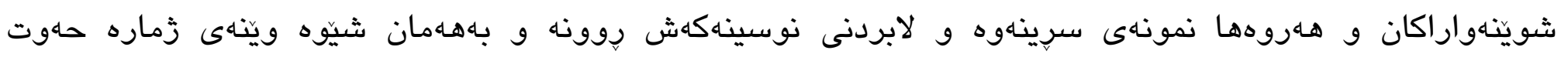

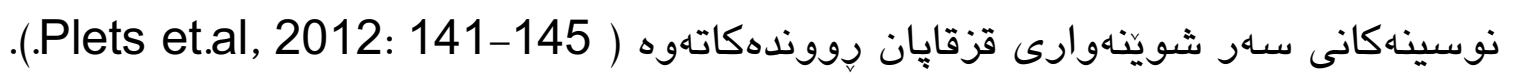




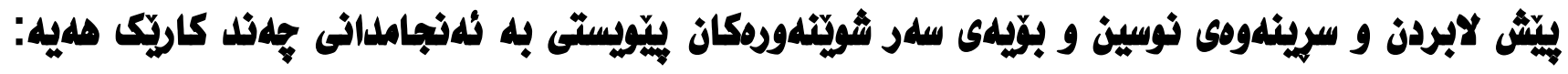

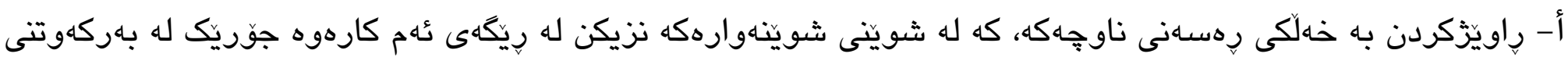

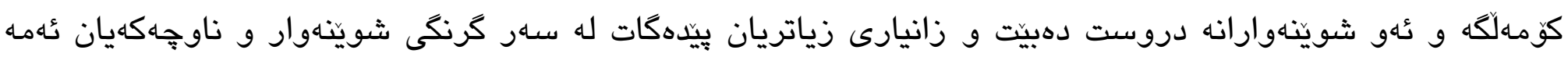

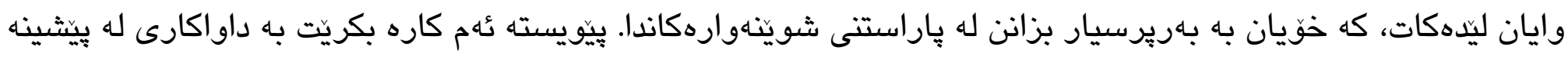

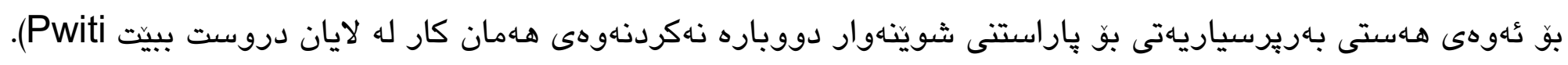
\& Chirikure, 2008: 468)

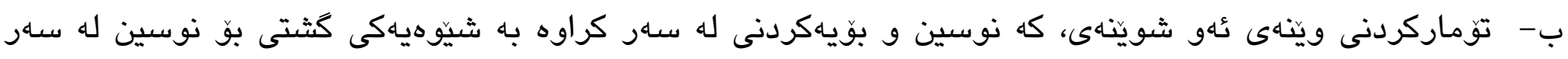

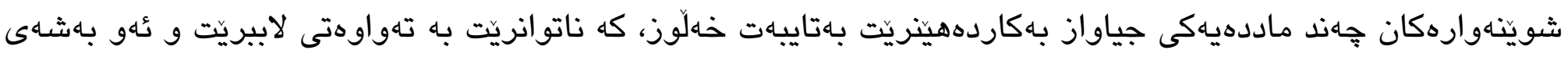

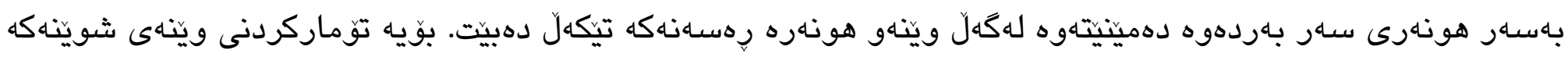

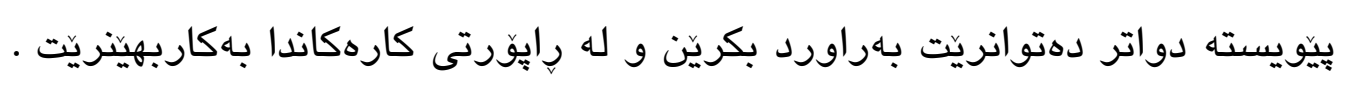

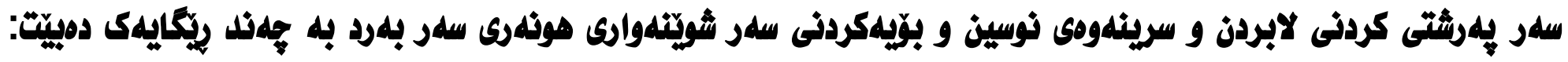

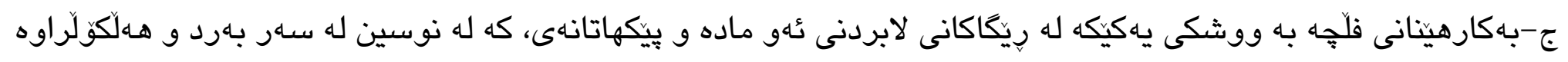

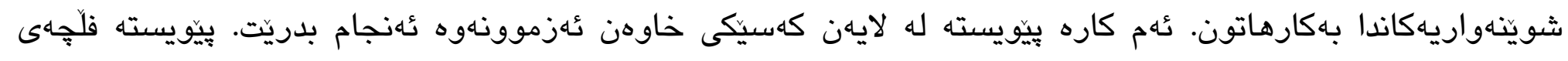

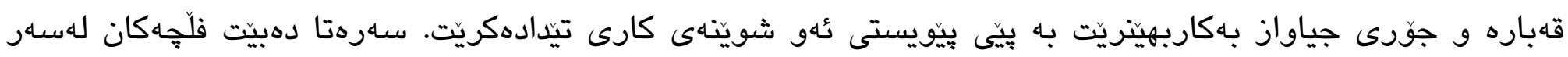

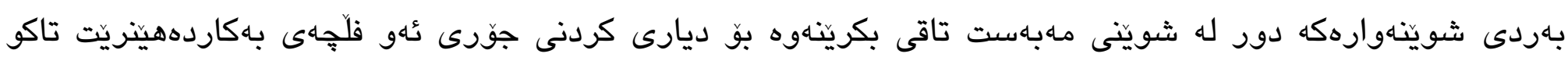

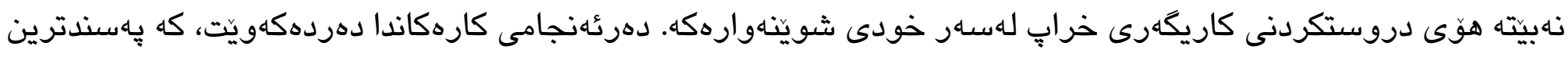

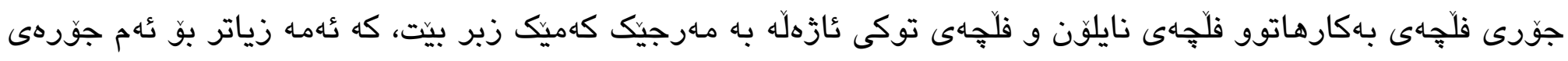

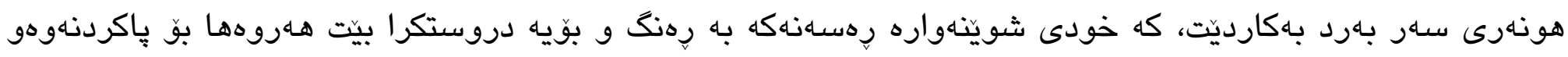

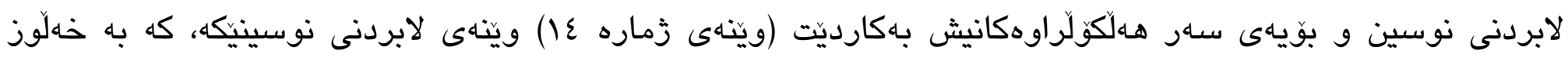

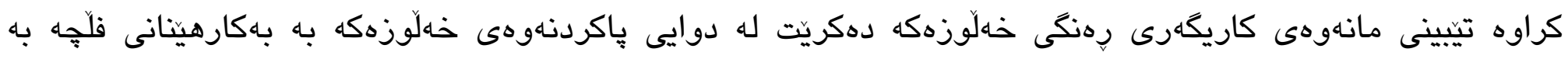

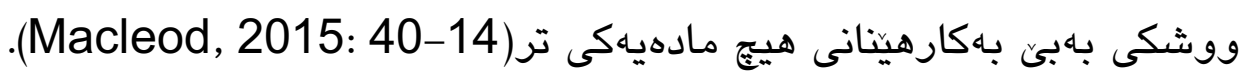

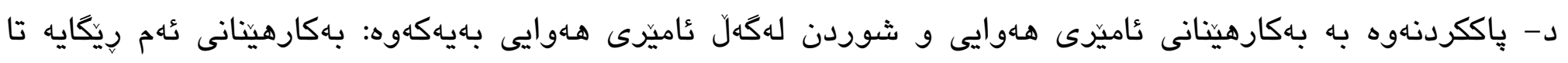

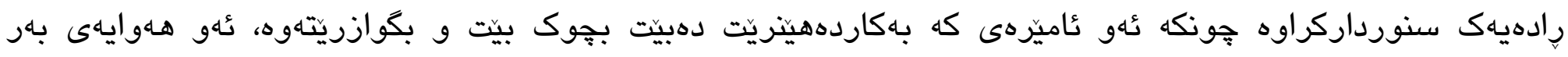

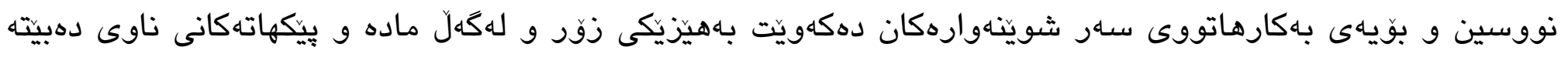




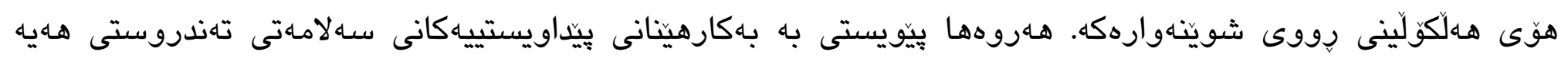

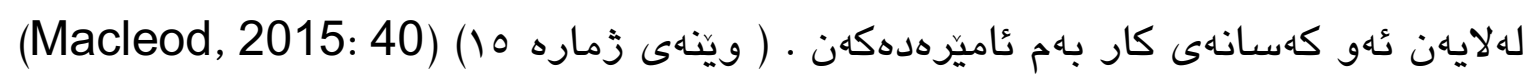
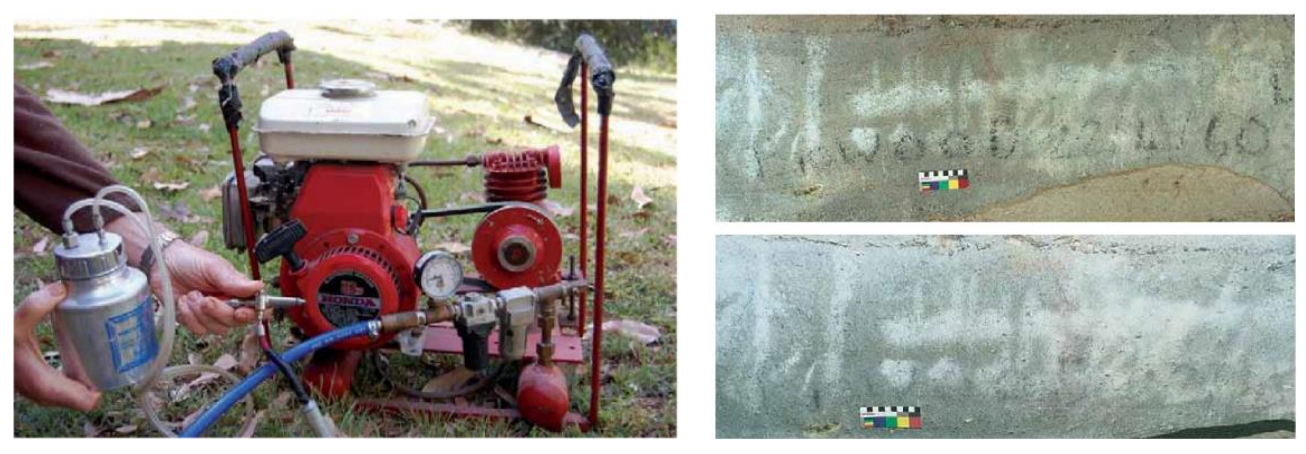

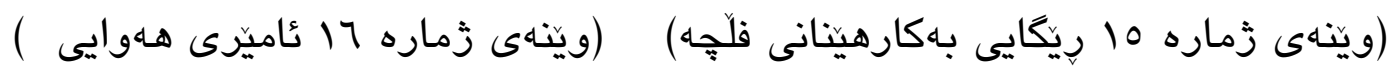

(figure 16 from, Lambert. D, 2008. Page 59) (figure 15 A from, Lambert. D, 2008. Page 64)

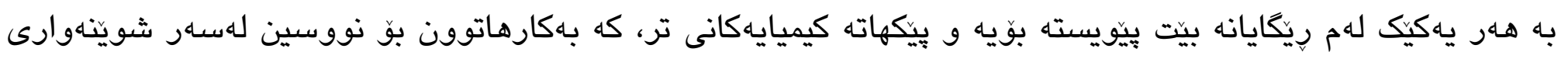

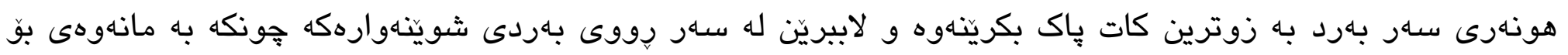

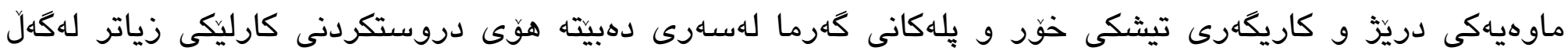

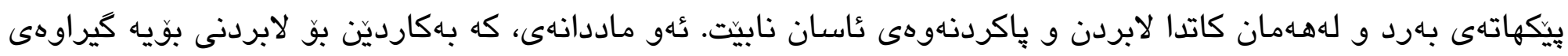

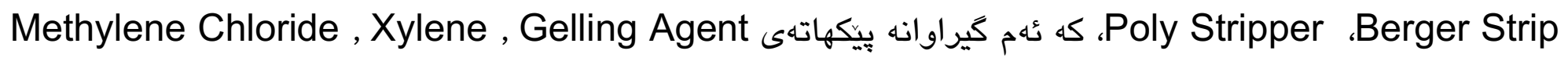

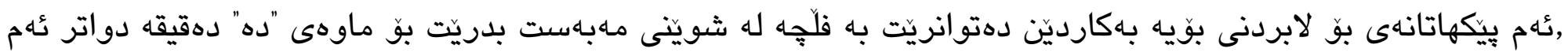

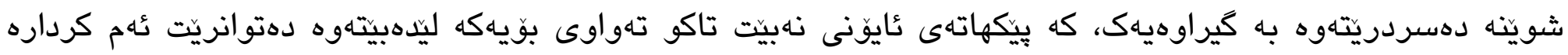

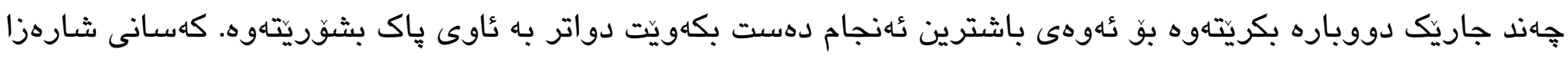

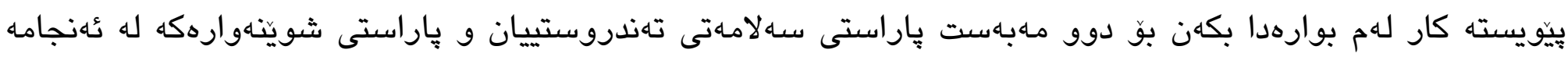

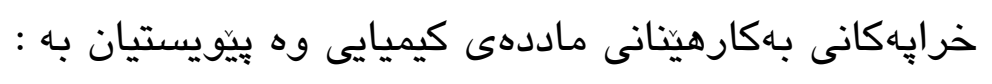

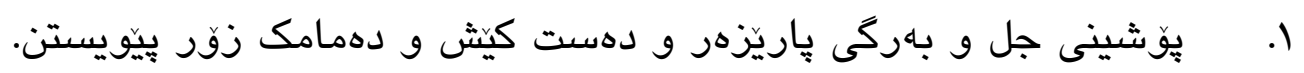

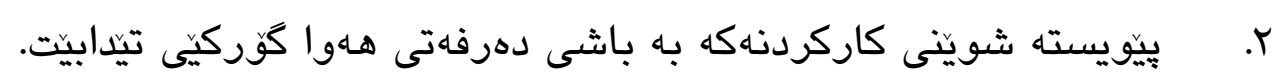

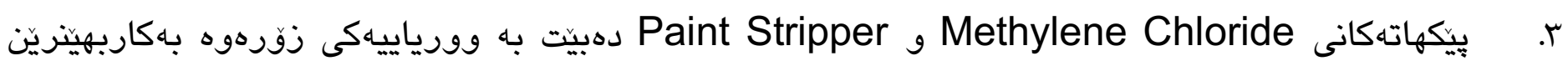

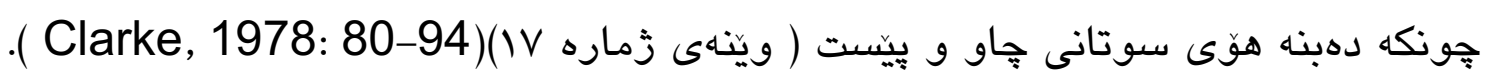



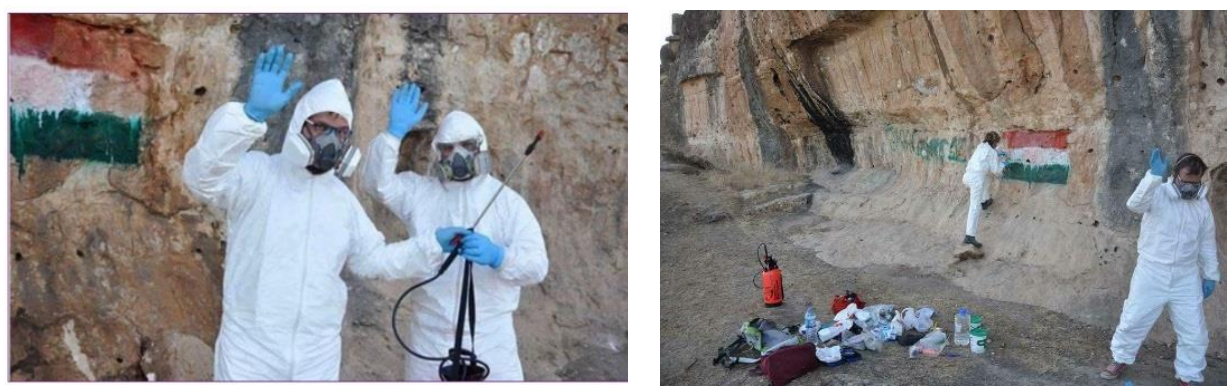

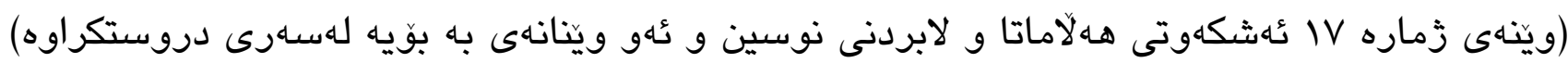
(figure 17 from, Jamie. Oconnell, 2017. Incident Report Feature: The Malthai Reliefs)

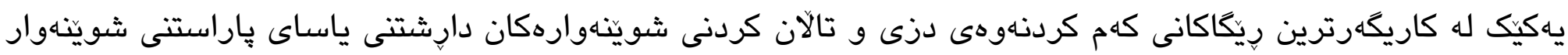

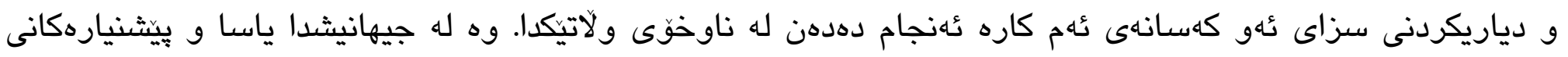

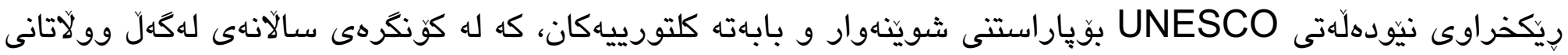

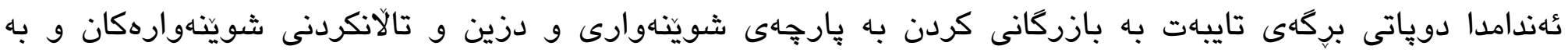

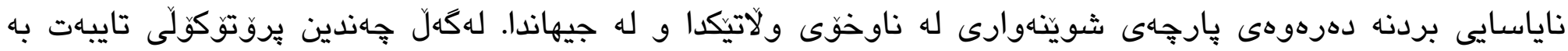

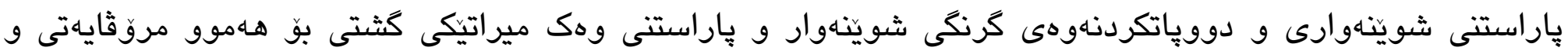

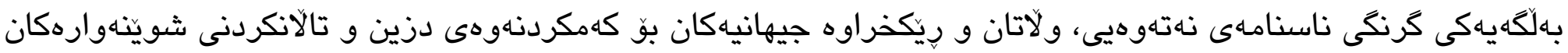

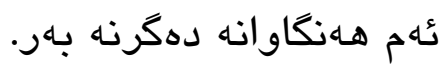

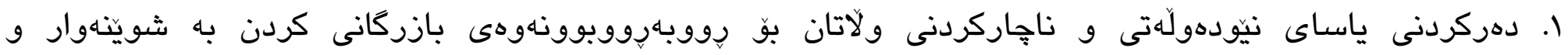

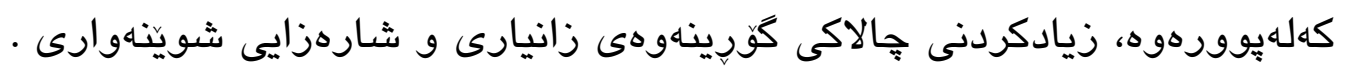

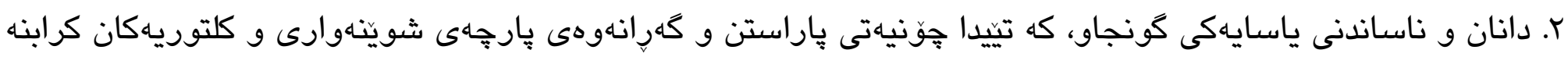
عُامانج.

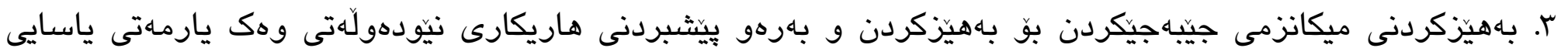

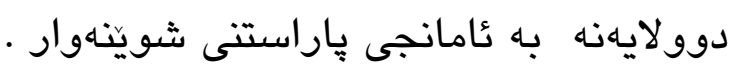




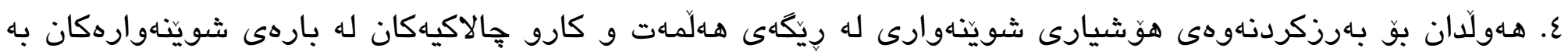

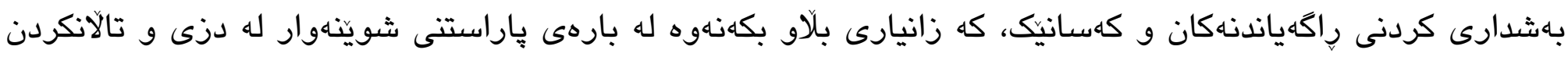
(UNODC/CCPCJ/EG.1, 2009: 1-15)

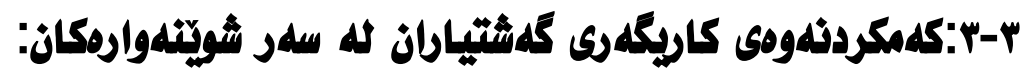

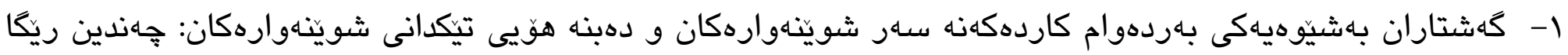

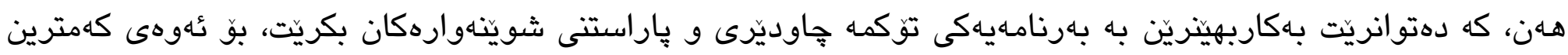

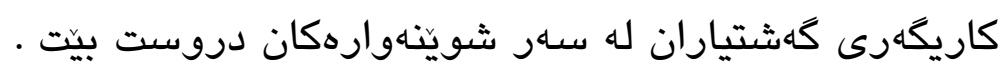

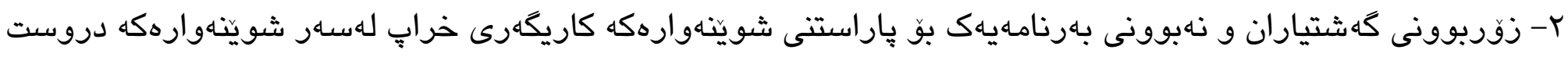

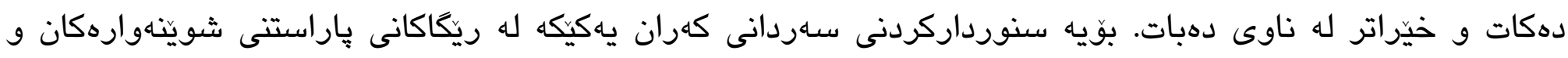
كهمكردنهوهى كاريكهرييه مروّيهكان .

ץ- دامهزراندنى جههد كهسيكى جالاك و بهتوانا وهك رابهرى كهشتيارى لهو شوينانهى، كه كَشتياران به زمارهيهكى زقر

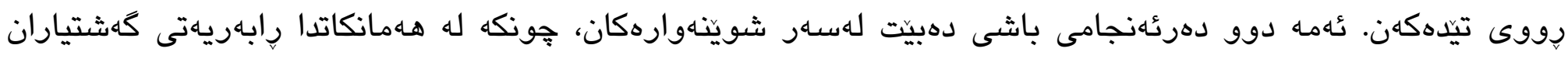

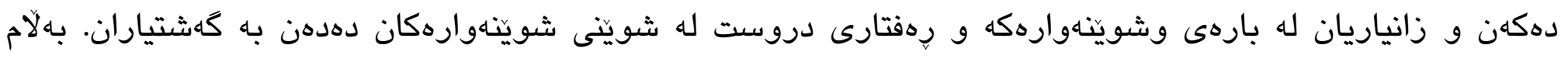

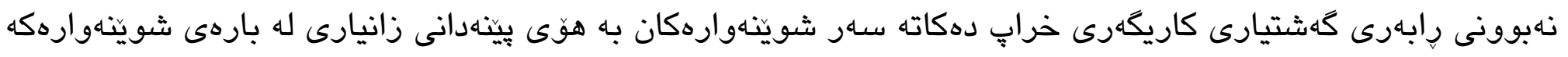

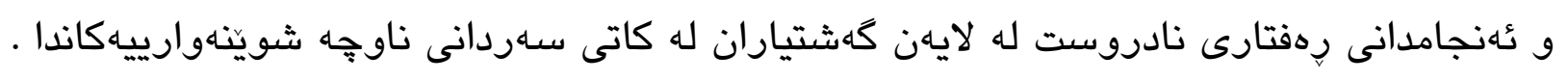

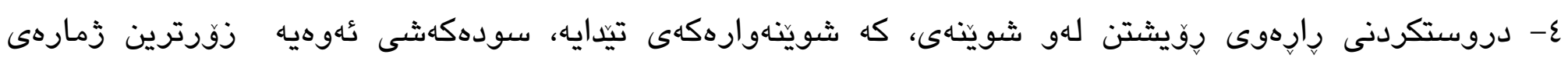

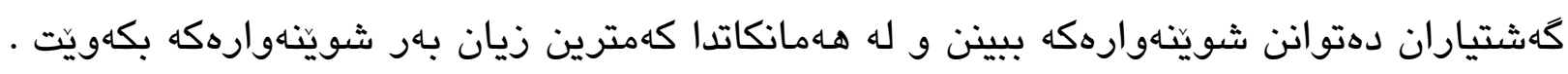

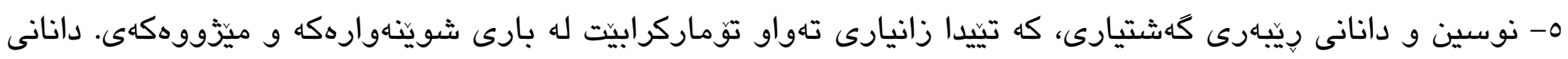

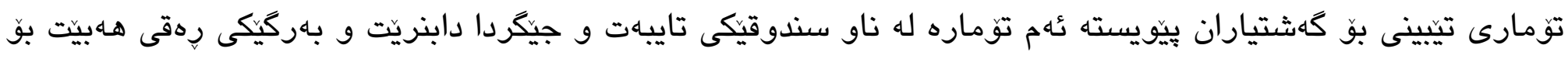

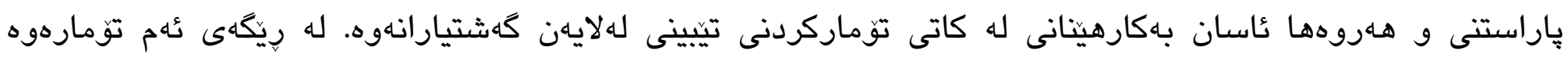

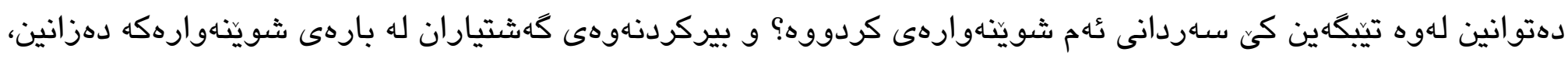

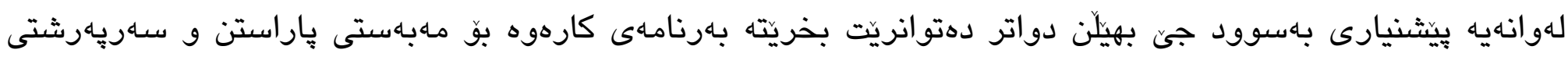

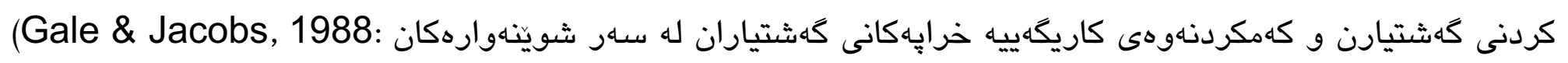
103-105 \& Mazel, 1983: 9) 


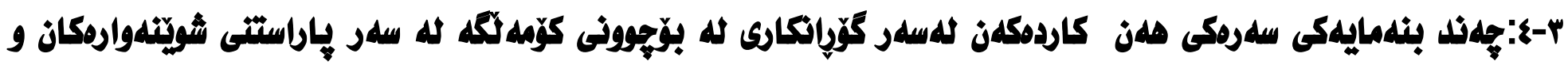 هوثلهرى سلdر بلهرد.}

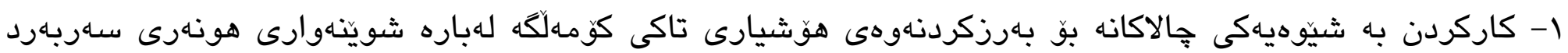

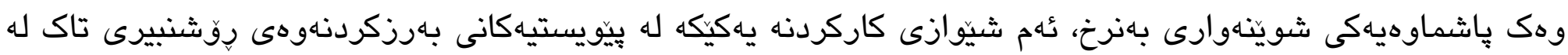

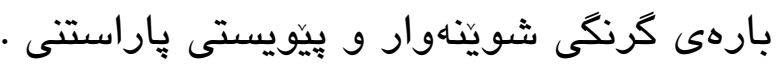

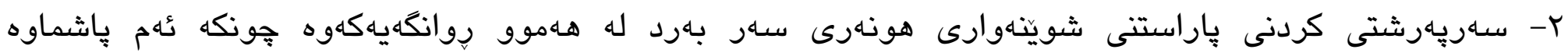

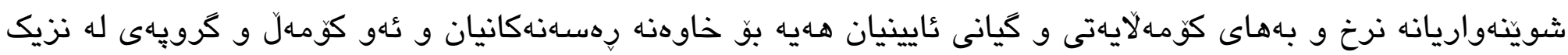

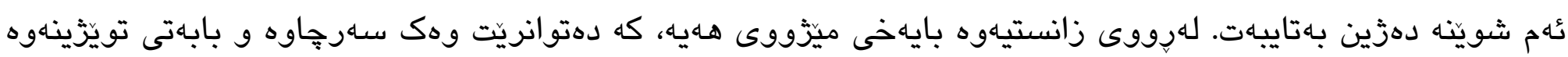

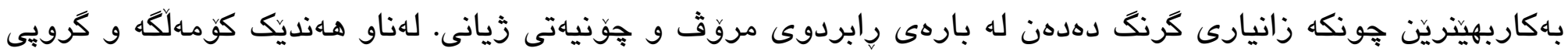

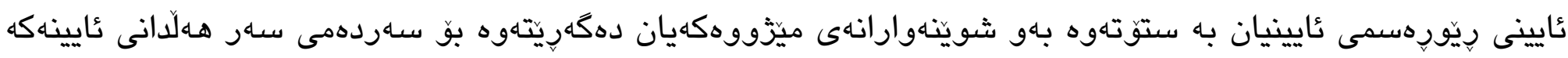

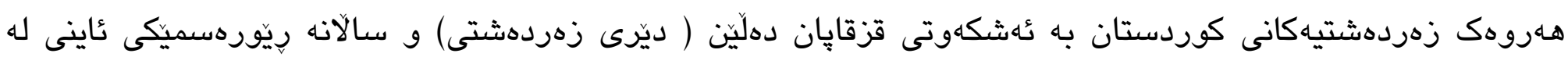

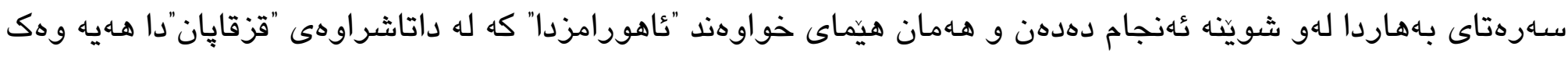

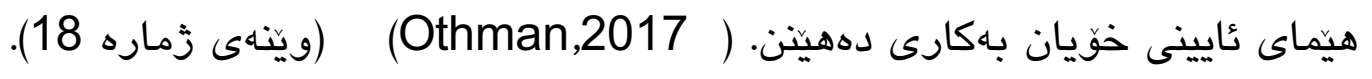

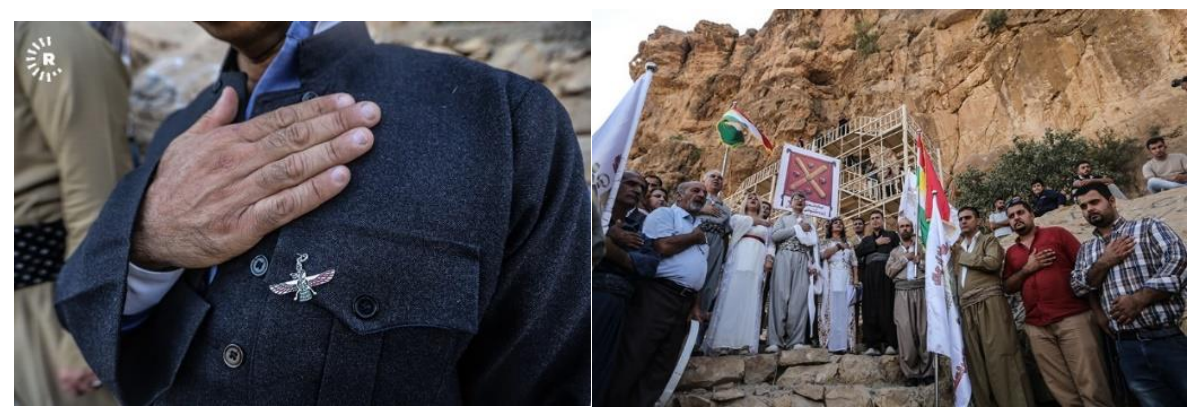

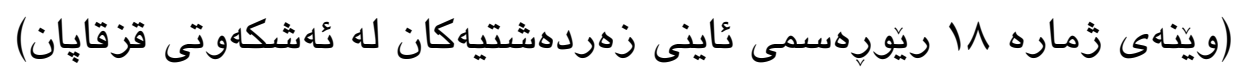

(figure 18 from, Othman, S. 2017. Kurdish Zoroastrians Celebrate Annual Ceremony Inside Sacred Cave. http://www.rudaw.net/english/kurdistan/130820171) 


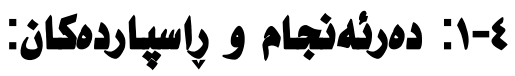

دهرئهنجامى ئهم تويَّينهوه دهرخستن و روونكردنهوهى شويَنهوارهكانى هونهرى سهار بهرد له كوردستان له

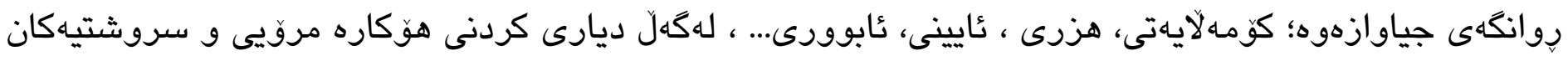

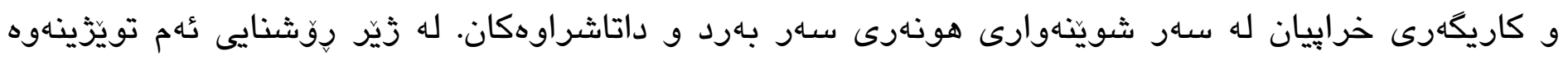

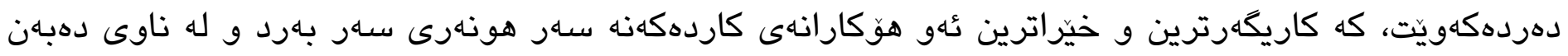

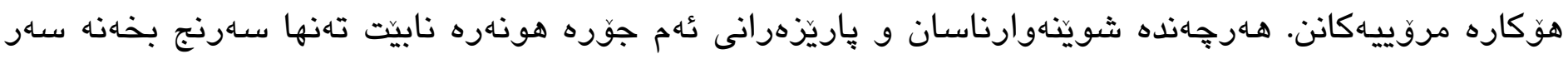

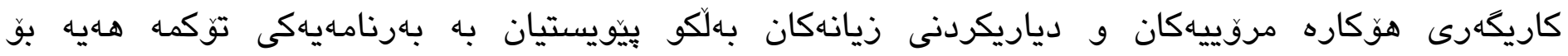

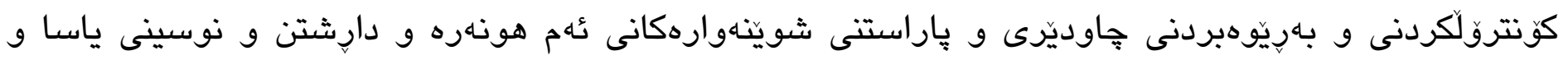

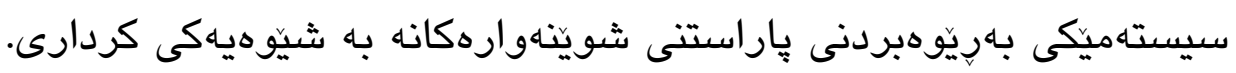

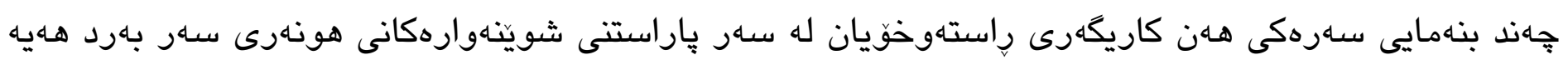

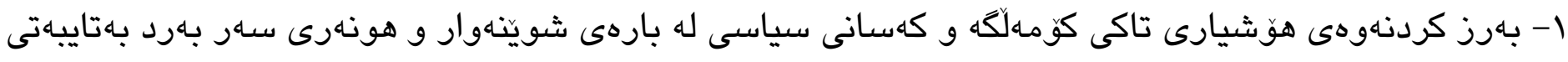

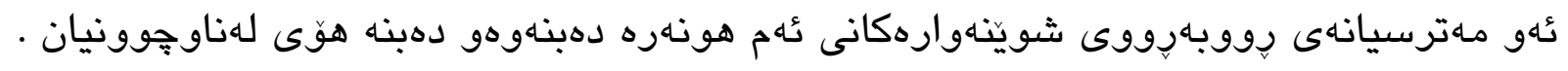

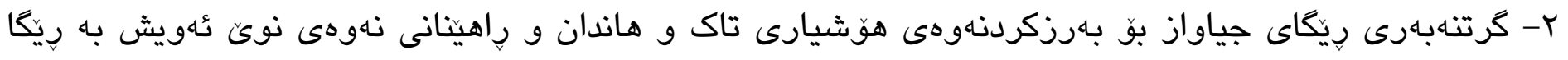

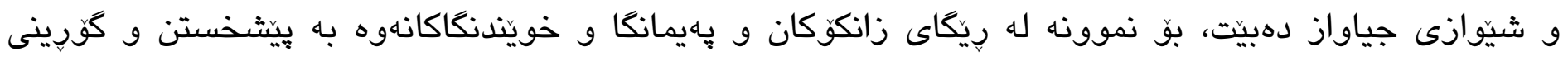

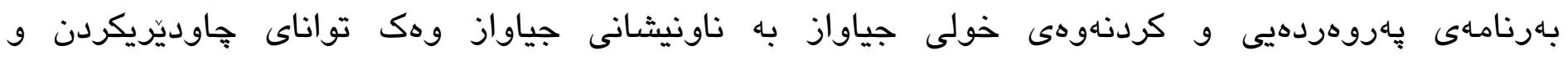

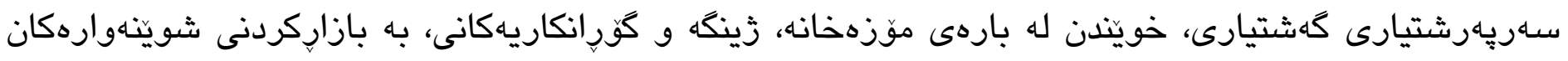

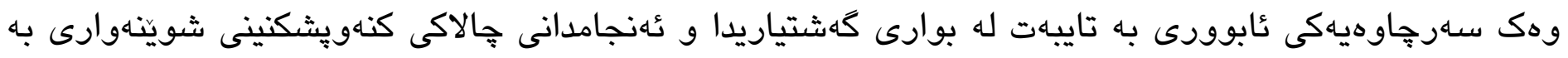

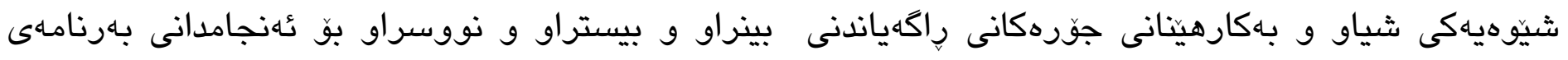

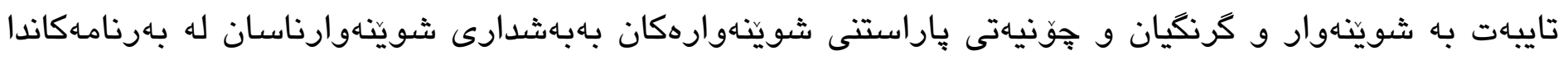

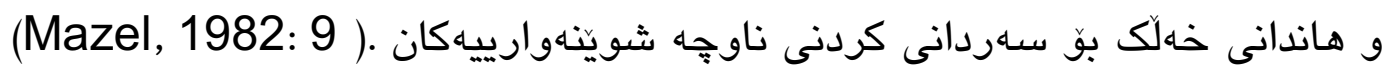

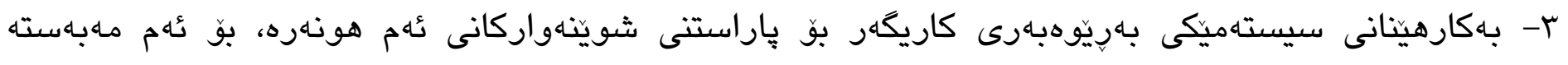

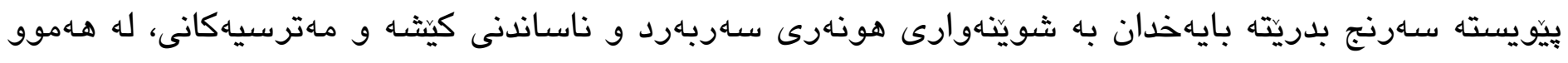

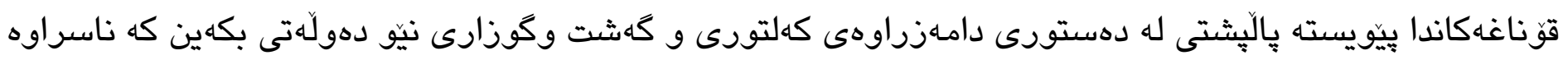
(ICOMOS, 2002). به بـ 
ع- كارئاسانى كردن و هاندانى كهرتى كهشتيارى بو بهرزكردنهوهى كرنكى كهشتيارى شويناهوارى و ئهمهش له

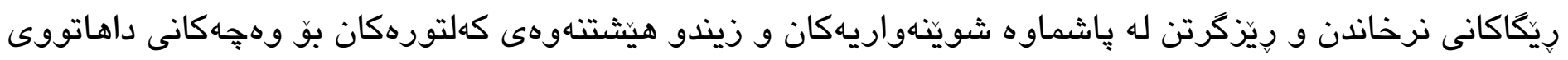
كؤمهل لكَه.

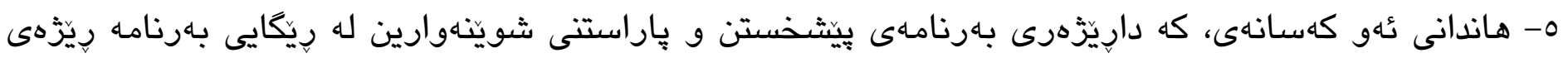

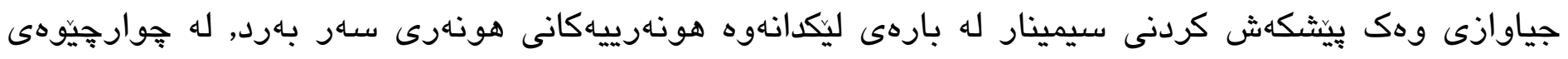

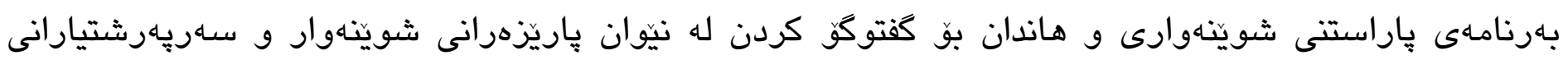

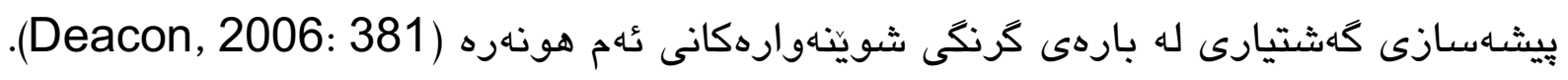




\title{
Rock Art (Rock Relief) in The Kurdistan Region of Iraq, Which Has Encountered The Threats of Disappearing
}

\author{
Rukhsar Ramadhan Ahmed \\ Halgurd High Schoool, Directorate Education of Rania, Ministry of Education, Kurdistan Region, \\ Iraq.
}

E-mail: rukhsar.ramazan@gmail.com

\begin{abstract}
Aras Ismail Khider
Archaeology Department, College of Art, Salahaddin University, Erbil, Kurdistan Region, Iraq.

E-mail: Aras.khider@su.edu.krd
\end{abstract}

\begin{abstract}
:
The Art rock is formed as pictures on strones which are made in different forms and in different ways including crafted pictures, status, maps, crafting on castle walls, and ancient temples, and coloured pictures, which can be founed on the stone shelters, mountan sides, and caves.

This ancient art reflects religious sprituality, cultural principles of community, and architecture framework of ancient communities. This study aims in showing the importance of this art in the archaeology of Kurdistan Region as national and regional treasure.
\end{abstract}


Here, this art form is crucial similar to the global archoleagy in the world, because this art form is a special way for seperatin community, teaching values and norms, origionality, as well as human relations to the earth they are living on.

Indicating the main natural and man-made factors such as; development, new construction, renovating some parts has negative influence on a portion of those archoloegical sites which has led to graffiti damages and intentional destrunction. Because, some of these archaeological sites are situated close to major touristes destinations which are another drawback for getting access to the sites without considering the human actions in those places. In this regard, being careless, and having limited awareness and information about the importance of archaeology and considering it as a national wealth has led to devastation of some significant sites. Aside from the human factors, natural disasters have left a negative influence on the archaeological sites in the Kurdistan Region.

This research is composed of the following parts: the first section introduces the history of rock art and the types of this art, the objectives, and human intentions in drawing and crafting those symbols, and pictures that human beings have produced in the ancient times. The second part of this research highlights the human and natural factors that have put pressure on those important archaeological sites which are facing threats.

The last part focuses on the findings, and recommendations; such as highlighting some of the legal principles, which aim to reduce the risks and pressure on rock art and their destruction. It will also include important procedures for spreading awareness of these sites to individuals and the wider community regarding archaeology and the need to protect the region's tangible heritage.

Key words: Rock Art, Archeological Sites, Human-Natural Factors, Kurdistan Region. 
Agnew et. Al. 2007. Rock Art a Cultural Treasure at Risk. The Getty conservation institute.

Amin, O. S. M. 2014. The Rock Relief of Harir ( Hareer), Iraqi Kurdistan.

https://www.researchgate.net/publication/309843381.

Amin, O. S. M. 2018. The Rock-Cut Tombs of Qizqapan, Iraqi Kurdistan: Median or Achaemenid. https://www.researchgate.net/project/Ancient-History-Encyclopedia https://www.researchgate.net/publication/322959187_The_Rock-

Cut_Tombs_of_Qizqapan_Iraqi_Kurdistan_Median_or_Achaemenid

Bady, L. M et. Al. 2010. Rock Art Conservation and Termite Management in Torres Strail, NE Australia. Rock Art Research. Vol. 27, No. 1. Pp 1-17.

Bauer, Alexander A.2015 "The Destruction of Heritage in Syria and Iraq and Its Implications. " International Journal of Cultural Property 22.1.

Burtenshaw, P \& Gould, O.G. 2014. Archaeology and Economic Development, Public Archaeology, Vo,13. No, 1-3, pp. 3-9. (Online) Journal homepage: https://www.tandfonline.com/loi/ypua20

Clarke, J. 1978. Conservation and Restoration of Paintings and Engraving Sites in Western Australia. In Pearson (ed),Conservation of Rock Art, Proceedings of the International Workshop on the Conservation of Rock Art, Perth, September 1977, institute for the Conservation of Cultural Material, Sydney.

Darvill, T \& Fernandes, A. P. B. 2014. Open-Air Rock- Art Preservation and Conservation: Acurrent State of Affairs. At: https://www.researchgate.net/publication/298713392.

Deacon, j. 2006. Rock Art Conservation and Tourism. Journal of Archaeological Method and theory. Vol.13, No. 4, Advances in the study of Pleistocene Imagery and Symbol Use [Part I] (Dec., 2006), pp. 379-399 :

https://www.jstor.org/stable/20177546.

Edmand, C. J. 1928. Two More Ancient Monuments in Southern Kurdistan. The Geographical Journal, Vol. 72, No. 2 (Aug., 1928), pp. 162-163. https://www.jstor.org/stable/1783042. 
Fernandes, A. P. B. 2009. Vandalism, Graffiti or 'just' rock art? The case of a recent engraving in the Côa Valley rock art complex in Portugal. In Congresso Internacional da IFRAO 2009, Piauí, Brasil. IFRAO, p. 729-74.

Hall, N. 1999. Building Blocks and Stepping Stones: Some Key Foundations in the Development of Rock Art Conservation in Australia. Archaeology in Oceania, Vol. 34, No. 3, Making a Mark: Papers on Rock Art for Andrée Rosenfeld (Oct., 1999), pp. 161-170.

Hanna, R \& Barber, M. 2017. ERASING ASSYRIANS: How the KRG Abuses Human Rights, Undermines Democracy, and Conquers Minority Homelands.www.assyrianconfederation.com info@ assyrianconfederation.com .

Lambert, D. 1989. Conserving Australia Rock Art- A manual for site manage manager. The institute Report series. Aboriginal studies press, Canberra.

Lambert, D. 2007. Introduction to Rock art conservation, A Guide to the preservation of Aboriginal Rock Art culture and Heritage Division, published, Department of Environment and Climate change ( NSW).

Lambert, D.J.1979. Natural Silica Formation over Aboriginal charcoal drawing near Gosford NSW.ICCM. Bull.5(2) 45.8 .

Lenzerini, Francesco Francioni Frederieo. (2013). "The Destruction of the Buddha's of Bamiyan and International Law.” 2003Eur. J. Int'l L.(14) 635.

Maclead, I. 2000. Rock Art Conservation and Management: The Past, Present and Future Option. Studies in Conservation. At: https://www.researchgate.net/publication/272313630.

Malko, H. et al. 2014. Neo-Assyrian Rock Reliefs: Ideology and Landscapes of an Empire. Monuments. Department of Art History and Archaeology, Columbia University. All rights reserved.

Mazel, A.D. 1082. Principles for Conserving the Archaeological Resources of the Natal Drakensberg. The South African Archaeological Bulletin, Vol. 37, No. 135 (Jun., 1982), pp. 7-15: https://www.jstor.org/stable/3888576. 
Othman, S. 2017. Kurdish Zoroastrians Celebrate Annual Ceremony Inside Sacred Cave. http://www.rudaw.net/english/kurdistan/130820171.

Plets, G. et al. 2012. The Deteriorating Preservation of the Alta Rock Art- Assessing Three. Dimensional Image. Based Modelling in Rock Art Research and Management. Vo.29, No.2. Pp 139-156.G.PLETS.

Pwiti, G \& Chirikue،Sh. 2008. Community Involvement in Archaeology and Cultural Heritage Management: An Assessment from Case Studies in Southern Africa and Elsewhere. Current Anthropology, Vol. 49, No. 3 (June 2008), pp. $467-485$.

Rosenfeld, A. 1985. Rock Art Conservation in Australia. Special Australian Heritage Publication. No. 2, Australian Government Publication Service, Canberra.

Unisco ; 1984, The protedion of moveble cultural property, Paris .

Unisco 2004:Atelier euro meghrebin et amenagment du territoire 1 672rcheology preventive 26-30 november alger.

Unite Nations Educational2010; Scientific and cultueral organization, Erbil conservation hand book , Inventory of Heritage buildings and urban analysis, Desember.

UNODC/CCPCJ/EG.1.2009. Protection Against Trafficking in Cultural Property.

Walsh, H. et al. 1984. Managing the Archaeological Sites of the Sandstone Belt, Central Queensland Aboriginal Corporation for Cultural Activities and Queensland National Parks and Wildlife service, Brisbane.

Watson, J. A. \& Flood, J. M. 1987. Termite and Wasp Damage to Australian Rock Art, Rock Art Research 4, 17-28.

Winkler, E.M. 1973. Tone: properties, Durability in Mans Environment, Springer Verlag, New York.

اتفاقيات جنيف الاربع لعام 9ع9 ام و بروتوكولاتها الاضافيين. 
اتفاقية الامم المتحدة لمكافحة الجريمة المنظمة عبر الوطنية ، فينا ـ . بم. اتفاقية القاهرة عام اتفاقية المعهد الدولى لتوحيد القانون الخاص (يونيدروا) عام 990 م. اتفاقية اليونسكو لحماية التراث الثقافى غير المادى ـ باريس ب. .بم.

اتفاقية باريس(9VY (م)، إتفاقية لحماية التراث العالمى الثقافى والطبيعى ، أقرها المؤتمر العام فى دورته السابعة عثرة فى 17 تثرين الثانى / نوفمبر - باريس · اتفاقية لحماية التراث العالمى الثقافى والطبيعى: 17 تشرينى الثانى / نوفمبر I9VT. باقر, طه \& فؤد, سفر. 977. بلدر الدين: صالح محمد،(999 (م)، حماية التراث الثقافى والطبيعى فى المعاهدات الدولية، دار النهضة العربية القاهرة، مصر.

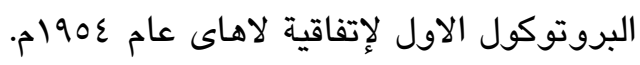

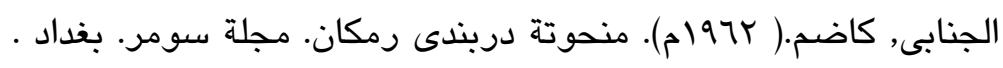
سوسـه, أحمد.( (1917). حضارة وادى الرافدين فى ضوء مشاريع الرى الزراعة و الكتشـاف

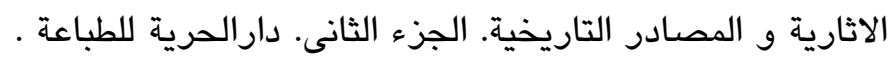
صالح, قعطان رشيد،(191VV). الكتشاف الاثرى فى العراق, بغداد .

العبدالله: سليمان عباس، ( 10 •rم)، الحماية الجزائيه للاثار فى التشريعات العربية ، أطروحة دكتوراه غير منشورة المقدمة لكلية الحقوق-

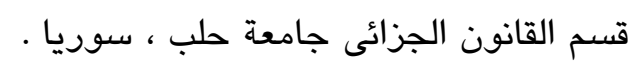
كوركيس, اشور،(·· (Y) شمال العراق, أشورى... أشورى ....أشورى .

المدور: هبة عبدالعزيز،(9 . بrم)، الحماية فى التعذيب فى إطار الإتفاقيات الدولية والاقليمية، منشورات الحلبى الحقوقية، بيروت، ط1. عاكرهيى: نجدت صبرى،(ع .rم) ، الإطار القانونى للآمن القومى ، مطبعة جامعة سهلاحهدين، أربيل. 